Open Access

\title{
Defining the value of CD56, CK19, Galectin 3 and HBME-1 in diagnosis of follicular cell derived lesions of thyroid with systematic review of literature
}

Duško Dunđerović ${ }^{*}$, Jasmina Marković Lipkovski ${ }^{1}$, Ivan Boričic ${ }^{1}$, Ivan Soldatović ${ }^{4}$, Vesna Božic ${ }^{2}$, Dubravka Cvejić ${ }^{3}$ and Svetislav Tatić ${ }^{1}$

\begin{abstract}
Background: Nodular follicular lesions of thyroid gland comprise benign and malignant neoplasms, as well as some forms of hyperplasia. "Follicular" refers to origin of cells and in the same time to growth pattern - building follicles. Nodular follicular thyroid lesions have in common many morphological features, therefore attempts were made to define additional criteria for distinction between follicular adenoma, follicular carcinoma and follicular variant of papillary carcinoma. Increasing number of immunohistochemical markers is in the continual process of evaluation.

Methods: Tissue microarrays incorporating, total 201 cases, out of which 122 malignant and 79 benign follicular lesions, including neoplastic and non-neoplastic, were constructed and immunostained with antibodies to CD56, CK19, Galectin-3, HBME-1. Tissue cores were exclusively being acquired from tumour/lesion on interface with normal thyroid tissue. A systematic review of literature was done for period from the year 2001 to present time.

Results: All analysed markers may make a difference between benign lesions/tumours from differentiated thyroid carcinomas ( $p=<0.01$, for all markers). Expression of all markers is significantly higher in papillary carcinoma than in follicular adenoma $(p<0.01)$. Statistically significant difference in expression of Galectin-3 and CD56 between follicular carcinoma and follicular adenoma was registered $(p=0.043 ; p=0.028$, respectively). The only marker which expression showed statistically significant difference between adenoma and carcinoma of Hurthle cells was Galectin $3(p=0.041)$. CK19 and HBME-1 were significantly expressed more in papillary carcinoma as compared to follicular carcinoma.
\end{abstract}

Conclusion: Galectin 3 is most sensitive marker for malignancy, while loss of expression of CD56 is very specific for malignancy. Expected co-expression for combination of markers in diagnosis of follicular lesions decreases sensitivity and increases specificity for malignancy.

Keywords: Thyroid, Immunohistochemistry, Tissue Microarray, CD56, CK19, Galectin 3, HBME-1

\footnotetext{
*Correspondence: drdundjerovic@gmail.com

${ }^{1}$ Institute of Pathology, Faculty of Medicine, University of Belgrade, dr

Subotica 1, 11000 Belgrade, Serbia

Full list of author information is available at the end of the article
} 


\section{Background}

Pathology of thyroid gland is diverse. Nevertheless, from practical reasons, all lesions can be divided into two groups, with nodular and diffuse pattern of growth. The former group clinically manifested as thyroid nodules, comprise benign and malignant neoplasms, as well as some forms of hyperplasia [1].

Nodules of thyroid gland are very frequent. It was estimated that $5 \%$ of general population develop clinically obvious nodule. With introduction of better ultrasound facilities, the detection of non palpable nodules is on the rise, $20-67 \%$ of detected non palpable thyroid nodules [2].

Term "follicular" in thyroid gland has dual connotation, to have origin from follicular cells or building follicles (designating follicular pattern of growth). Lesions with follicular growth pattern could be further classified relative to size of follicles (micro-, macrofollicular), or in respect to presence of capsule (totally /partially encapsulated, non encapsulated). Universally, majority of follicular lesions could be classified into benign and malignant category. According to presence or absence of features in parenthesis (capsule, vascular/capsular invasion, papillary carcinoma type nuclei) we classify them as: adenomatoid nodules and adenomas, papillary thyroid carcinoma (PTC), follicular thyroid carcinoma (FTC), well differentiated tumours of uncertain malignant potential (WDT-UMP), follicular tumour of uncertain malignant potential (FT-UMP), well differentiated carcinoma, NOS, Hurthle cell adenoma/carcinoma [3-7]. Follicular nodular thyroid lesions have in common many morphological features, which frankly put a burden on pathologist while trying to make diagnosis on H\&E slides. Even amongst experienced endocrine pathologist there exists inter-observer variability. Furthermore, intra-observer variability is seen when they review the same H\&E slides after some period of time [8].

Attempts were made to define additional criteria for distinction of follicular adenoma (FA) from follicular carcinoma and follicular variant of papillary carcinoma, and between two later mentioned. Increasing number of immunohistochemical markers are being tested, and some are promising like CD56, Hector Battifora Mesothelial 1 (HBME-1), Galectin 3 (Gal-3) and Cytokeratin 19 (CK19) considering differential diagnosis, nevertheless, none of them is individually conclusive $[6,9]$.

The aim of this study was to test sufficient number of different follicular thyroid lesions using for that purpose tissue microarray (TMA) technology, exploiting all four above mentioned markers. Our intention is to try to obtain answers to following questions: Can they distinct benign from malignant lesions?; Can they differentiate between papillary carcinoma (especially follicular variant) from follicular carcinoma or adenoma; Could they differentiate follicular adenoma from follicular carcinoma? We hypothesized that not just one combination but acceptable number of well-tailored combinations of immunohistochemical markers should suit for different differential diagnostic combinations. Elaborated review of literature on expression of CD56, CK19, HBME-1, Gal-3 is also provided.

\section{Methods \\ Case selection}

This retrospective study was conducted on 201 cases of thyroid lesions, including 44 males and 157 females. Majority of cases were from $2013^{\text {th }}$, and $2014^{\text {th }}$, but due to the paucity of cases with follicular thyroid carcinoma, aforementioned cases were selected retrospectively all the way till the year of $2007^{\text {th }}$. The research was approved by Ethical committee of Medical Faculty, University in Belgrade. Cases were selected from archives of Department for endocrine pathology, Center for endocrine surgery, Clinical centre of Serbia. Glass slides (on average 7 per case) were retrieved and evaluated by three experienced endocrine pathologists, who were unaware of clinical information and previous diagnosis. Diagnosis for problematic cases was made by consensus of two pathologists. Examination comprised 122 malignant and 79 benign follicular lesions. Only tumours with diameter larger than $5 \mathrm{~mm}$ were included in the study.

\section{TMA}

Four high density TMAs were constructed manually. Area of interest was the zone right beneath tumour capsule or just on invasive tumours front. Previously marked area of interest on slides was translated to corresponding regions of donor paraffin blocks. Needle with inner diameter of $1.1 \mathrm{~mm}$ was used to create and transfer tissue cores $\left(0.785 \mathrm{~mm}^{2}\right.$ cross cut surface area) in recipient paraffin blocks. Two cores were taken from every lesion. Cases with at least one section across all slides were regarded as valid. Tissue cores with external controls were included in all TMAs. Final TMA blocks consisted of 104 cores (13x8), plus five control tissue cores. Control tissues included in TMA were normal thyroid tissue, follicular thyroid adenoma, mucosa of appendix (crypts positive to CK19 and Gal-3), serous membrane of appendix (mesothelial cell immunopositive for HBME-1), muscular layer of appendix (nerve fibers and ganglion cells positive for CD56).

\section{Immunohistochemistry}

Immunohistohemical staining with CD56 (NOVOCASTRA, Clone 1B6, 1:50), HBME-1 (DAKO, Clone HBME1, 1:50), CK19 (DAKO, Clone RCK 108, 1:50), Galectin-3 
(R\&D SYSTEMS, Clone 194804, 1:100) was done manually according to manufacturers instructions (Table 1).

\section{Evaluation of immunohistochemical staining}

Cytoplasmatic \pm nuclear immunoreactivity for Gal-3, membranous \pm cytoplasmatic immunoreactivity for CK19, and membranous \pm cytoplasmatic immunoreactivity for HBME1 in more than $10 \%$ of cells was considered as positive staining without regard to intensity of staining. In respect to distribution of staining we graded staining as $1,2,3,4$, when $11-25 \%, 26-50 \%, 51-75 \%, 76-100 \%$ of tumours cells show expression, respectively [10].

Membranous staining of follicular cells with CD56 was regarded as positive. On the grounds that CD56 expression is reduced or missing in thyroid carcinomas, positive result (or malignant profile) was scored as 1 when 0-10 \% follicular cells is immunoreactive for CD56. Score 0 (negative) was in the case that equal or more than $11 \%$ of follicular cells were positive for CD56 [11].

\section{Statistical analysis}

Database and data analyses were done with IBM SPSS Statistics 20. Descriptive and analytical methods were used. For comparison of variables, parametric $(t$ test, ANOVA) and non-parametric tests (chi square, Mann Whitney $U$ test, Kruskal Wallis test) were employed. With objective to compare markers Receiver Operating Curve (ROC) was constructed. Sensitivity, specificity, positive and negative predictive values, and diagnostic odds ratio were calculated for single and combination of markers in program MedCalc ${ }^{\circ}$ (Version 10.2.0.0). Probability values less than 0.05 were considered statistically significant.

\section{Review of literature}

Review of literature was done in PUBMED for period from the year 2001 to present time. The following describers were used ((CK-19 and thyroid) OR (GALECTIN-3 and thyroid) OR (HBME-1 and thyroid) OR (CD56 and thyroid). We included studies which contain benign as well as malignant cases, and which employ tissue immunohistochemistry as technique. The following information was acquired: reference, number of benign and malignant cases, histological types of neoplasms studied and results (stratified into two groups: true positive, true negative, false positive, false negative). Our results were compared with different studies.

\section{Results}

Average age of patients was $51 \pm 14$ years, with median of 53. Comparing benign with malignant group, matched relative to sex, and relative to age, we found no statistical difference between groups $(p=.134 ; p=.051$, respectively). The mean size of benign and malignant lesions was $3.3 \mathrm{~cm}$ (range, 0.5 to $9.0 \mathrm{~cm}$ ) and $3.4 \mathrm{~cm}$ (range 0.5 to $12.0 \mathrm{~cm}$ ), respectively $(p=.719)$. Malignant group consisted of 87 papillary thyroid carcinomas, 15 follicular thyroid carcinomas and 20 Hurthle cell carcinomas. Benign lesions included 27 follicular adenomas, 10 Hurthle cell adenomas, 12 hyperplastic adenomas, and 30 nodular goiters (colloid adenomas). The group of papillary carcinomas was represented by 40 follicular type, 27 classic type, 9 mixed, 5 solid and 3 oxyphilic type carcinomas.

CK19 expression was present in $75 \%$ of malignant tumours, generally with high intensity and wide distribution, and in $29.1 \%$ of benign lesion, usually with weak and focal expression $(p=.000)$ (Tables 2 and 3). Immunoreactivity was cytoplasmatic, sometimes with membranous accentuation (Fig. 1). Among carcinomas, difference in expression of CK19 existed between papillary carcinoma and follicular carcinoma $(p=.000)$. Differences in expression were significant between papillary carcinoma and follicular adenoma $(p=.000)$, as well as between follicular variant of papillary carcinoma and follicular carcinoma $(p=.004)$ or adenoma $(p=.000)$. When we excluded papillary carcinoma from the sample we found statistical significance between malignant and benign group $(p=0.045)$. Significant difference in expression of CK19 was not found between follicular adenoma and follicular carcinoma $(p=.433)$, or between Hurthle cell adenoma/carcinoma $(p=.894)$. ROC curve (Fig. 2) was constructed, and value higher than $9.5 \%$ of positive

Table 1 Immunohistochemistry

\begin{tabular}{|c|c|c|c|c|c|c|c|}
\hline Antibody & Clone & Manufacturer & Dilution & Pretreatment & $\begin{array}{l}\text { Incubation with } \\
\text { primary antibody }\end{array}$ & $\begin{array}{l}\text { Visualisation kit } \\
\text { manufacturer }\end{array}$ & $\begin{array}{l}\text { Visualisation } \\
\text { kit }\end{array}$ \\
\hline $\begin{array}{l}\text { CD56 } \\
\text { (NCAM) }\end{array}$ & $1 \mathrm{B6}$ & Novocastra, UK & $1: 50$ & $\begin{array}{l}\text { microwave oven, 20', citrate } \\
\text { buffer, pH6 }\end{array}$ & $1 \mathrm{~h}$ & $\begin{array}{l}\text { Thermo Scientific }{ }^{\mathrm{TM}} \text {, } \\
\text { USA }\end{array}$ & TL-125-HL \\
\hline $\begin{array}{l}\text { Cytokeratin } \\
19\end{array}$ & RCK108 & $\begin{array}{l}\text { Dako, Denmark a/ } \\
\text { s }\end{array}$ & $1: 100$ & $\begin{array}{l}\text { enzime digestion, preteinase } \mathrm{K} \text {, } \\
10^{\prime} \text {, room temp }\end{array}$ & $30^{\prime}$ & $\begin{array}{l}\text { Thermo Scientific }{ }^{\mathrm{TM}}, \\
\text { USA }\end{array}$ & TL-125-HL \\
\hline HBME-1 & $\begin{array}{l}\text { HBME- } \\
1\end{array}$ & $\begin{array}{l}\text { Dako,Denmark A/ } \\
\text { S }\end{array}$ & $1: 50$ & $\begin{array}{l}\text { microwave oven, } 20 \text { ', citrate } \\
\text { buffer, } \mathrm{pH} 6\end{array}$ & $1 \mathrm{~h}$ & $\begin{array}{l}\text { Thermo Scientific }{ }^{\mathrm{TM}}, \\
\text { USA }\end{array}$ & TL-125-HL \\
\hline $\begin{array}{l}\text { Human } \\
\text { Galecin-3 }\end{array}$ & 194804 & $\begin{array}{l}\text { Techne/r\&d } \\
\text { systems, USA }\end{array}$ & $1: 100$ & $\begin{array}{l}\text { microwave oven, } 20 \text { ', citrate } \\
\text { buffer, pH6 }\end{array}$ & $12 \mathrm{~h}, 4^{\circ} \mathrm{C}$ & $\begin{array}{l}\text { Thermo Scientific }{ }^{\mathrm{TM}}, \\
\text { USA }\end{array}$ & TL-125-HL \\
\hline
\end{tabular}


Table 2 Expression of CK19, HBME-1, Galectin-3, CD56 in benign and malignant tumors

\begin{tabular}{|c|c|c|c|c|c|}
\hline \multirow[t]{3}{*}{ Markers } & \multirow[t]{3}{*}{ Expression } & \multicolumn{4}{|c|}{ Tumor } \\
\hline & & \multicolumn{2}{|c|}{ Benign } & \multicolumn{2}{|c|}{ Malignant } \\
\hline & & $\mathrm{N}$ & $\%$ & $\mathrm{~N}$ & $\%$ \\
\hline \multirow[t]{2}{*}{ CK 19} & + & 23 & $29.1 \%$ & 92 & $75.4 \%$ \\
\hline & - & 56 & $70.9 \%$ & 30 & $24.6 \%$ \\
\hline \multirow[t]{2}{*}{ HBME 1} & + & 12 & $15.2 \%$ & 87 & $71.3 \%$ \\
\hline & - & 67 & $84.8 \%$ & 35 & $28.7 \%$ \\
\hline \multirow[t]{2}{*}{ Galectin 3} & + & 28 & $35.4 \%$ & 108 & $88.5 \%$ \\
\hline & - & 51 & $64.6 \%$ & 14 & $11.5 \%$ \\
\hline \multirow[t]{2}{*}{ CD 56} & + & 6 & $7.6 \%$ & 71 & $58.2 \%$ \\
\hline & - & 73 & $92.4 \%$ & 51 & $41.8 \%$ \\
\hline
\end{tabular}

tumours cells had sensitivity of $75.4 \%$, and specificity $71 \%$ for carcinoma (Table 4).

Malignant tumors expressed intensively and widely HBME-1 antigen than benign lesions (71.3 \%; 15,2 \%, respectively; $p=.000$ ). Variation in immunoreactivity was significant between papillary and follicular carcinoma $(p=.000)$, papillary carcinoma and follicular adenoma $(p=.000)$, and between follicular variant of papillary carcinoma and follicular carcinoma/adenoma $(p=.009 ; p=.000$ respectively). Once again, no significant difference was found comparing follicular adenoma/ carcinoma $(p=.465)$ in respect to HBME-1 expression. The values equal or higher than $7.5 \%$ of follicular cells immunoreactive for HBME-1 had sensitivity of $71.3 \%$ and specificity of $85 \%$ for carcinoma.

Galectin-3 was expressed significantly more in malignant tumours $(88.5 \%)$ than in benign $(35.4 \%)(p=.000)$. Further, expression of Galectin-3 in papillary carcinoma and follicular variant of papillary carcinoma was notably higher than in follicular adenoma $(p=.000 ; p=.001$; respectively). We found no difference in expression between papillary and follicular carcinoma $(p=0.171)$, nor between follicular variant of papillary carcinoma and follicular carcinoma $(p=0.691)$. At last, follicular carcinoma had higher expression than follicular adenoma (0.043) and Hurthle cell carcinoma than Hurthle cell adenoma $(p=0.041)$. With cut off value of $7.5 \%$ of follicular cells expressing Galectin-3, sensitivity is $89 \%$, and specificity is $65 \%$ for carcinoma.

CD56 expression was lost in $58.2 \%$ of malignant lesions and $7.6 \%$ of benign lesions $(p=.000)$. Papillary carcinoma lost expression in $74.7 \%$ of cases, compared to follicular carcinomas $26.7 \%(p=.006)$, and follicular adenoma $3.7 \%(p=.000)$. No statistically significant difference in expression was observed between follicular variant of papillary carcinoma and follicular carcinoma $(p=.282)$, but there is a difference between follicular variant of papillary carcinoma and follicular adenoma $(p=.000)$. Interestingly, difference also existed between follicular carcinoma and follicular adenoma $(p=0.028)$, and between follicular carcinoma and benign thyroid lesions (without Hurthle cell adenomas; $p=0.006$ ) Having insight in ROC coordinates, the values less than $12.5 \%$ of follicular cells expressing CD56, have sensitivity of $58 \%$ and specificity of $92.4 \%$ for carcinoma.

Diagnostic value of all investigated markers and their combinations in differentiating malignant from benign thyroid follicular lesions was presented in a form of sensitivity, specificity, positive and negative likelihood ratios, disease prevalence, positive and negative predictive values, and odds ratio (Tables 5 and 6). Sensitivity and specificity for different combinations of markers in respect to various histopathological entities were presented in Table 7.

Review of literature was presented within tables (Tables 8 , 9, 10, 11 and 12). Sensitivity and specificity for different combinations of entities, taking into account all available cases from reviewed studies, including current study is discussed (Table 13).

\section{Discussion}

This tissue microarray based study is a unique in a methodological way because it gives information of expression of investigated markers on tumour front. It

Table 3 Number and percent of cases with positive expression within different pathohistological entities

\begin{tabular}{|c|c|c|c|c|c|c|c|c|c|}
\hline \multirow[t]{2}{*}{ PH diagnosis } & \multirow{2}{*}{$\begin{array}{l}\text { No } \\
\text { of } \\
\text { cases }\end{array}$} & \multicolumn{2}{|c|}{ CK 19} & \multicolumn{2}{|c|}{ HBME 1} & \multicolumn{2}{|c|}{ Galectin 3} & \multicolumn{2}{|c|}{$\mathrm{CD} 56^{\mathrm{a}}$} \\
\hline & & $\bar{N}$ & $\%$ & $\bar{N}$ & $\%$ & $\bar{N}$ & $\%$ & $\bar{N}$ & $\%$ \\
\hline Colloid adenoma & 30 & 11 & $36.7 \%$ & 1 & $3.3 \%$ & 4 & $13.3 \%$ & 4 & $86.70 \%$ \\
\hline Follicular adenoma & 27 & 6 & $22.2 \%$ & 4 & $14.8 \%$ & 11 & $40.7 \%$ & 1 & $96.30 \%$ \\
\hline Hurthle cell adenoma & 10 & 6 & $60.0 \%$ & 7 & $70.0 \%$ & 5 & $50.0 \%$ & 1 & $90.00 \%$ \\
\hline Hyperplastic adenoma & 12 & 0 & $0.0 \%$ & 0 & $0.0 \%$ & 8 & $66.7 \%$ & 0 & $100.00 \%$ \\
\hline Follicular carcinoma & 15 & 5 & $33.3 \%$ & 4 & $26.7 \%$ & 11 & $73.3 \%$ & 4 & $73.30 \%$ \\
\hline Hurhle cell carcinoma & 20 & 12 & $60.0 \%$ & 17 & $85.0 \%$ & 17 & $85.0 \%$ & 2 & $90.00 \%$ \\
\hline Papillary carcinoma & 87 & 75 & $86.2 \%$ & 66 & $75.9 \%$ & 80 & $92.0 \%$ & 65 & $25.30 \%$ \\
\hline
\end{tabular}

ammunopositivity in $>10 \%$ follicular cells 


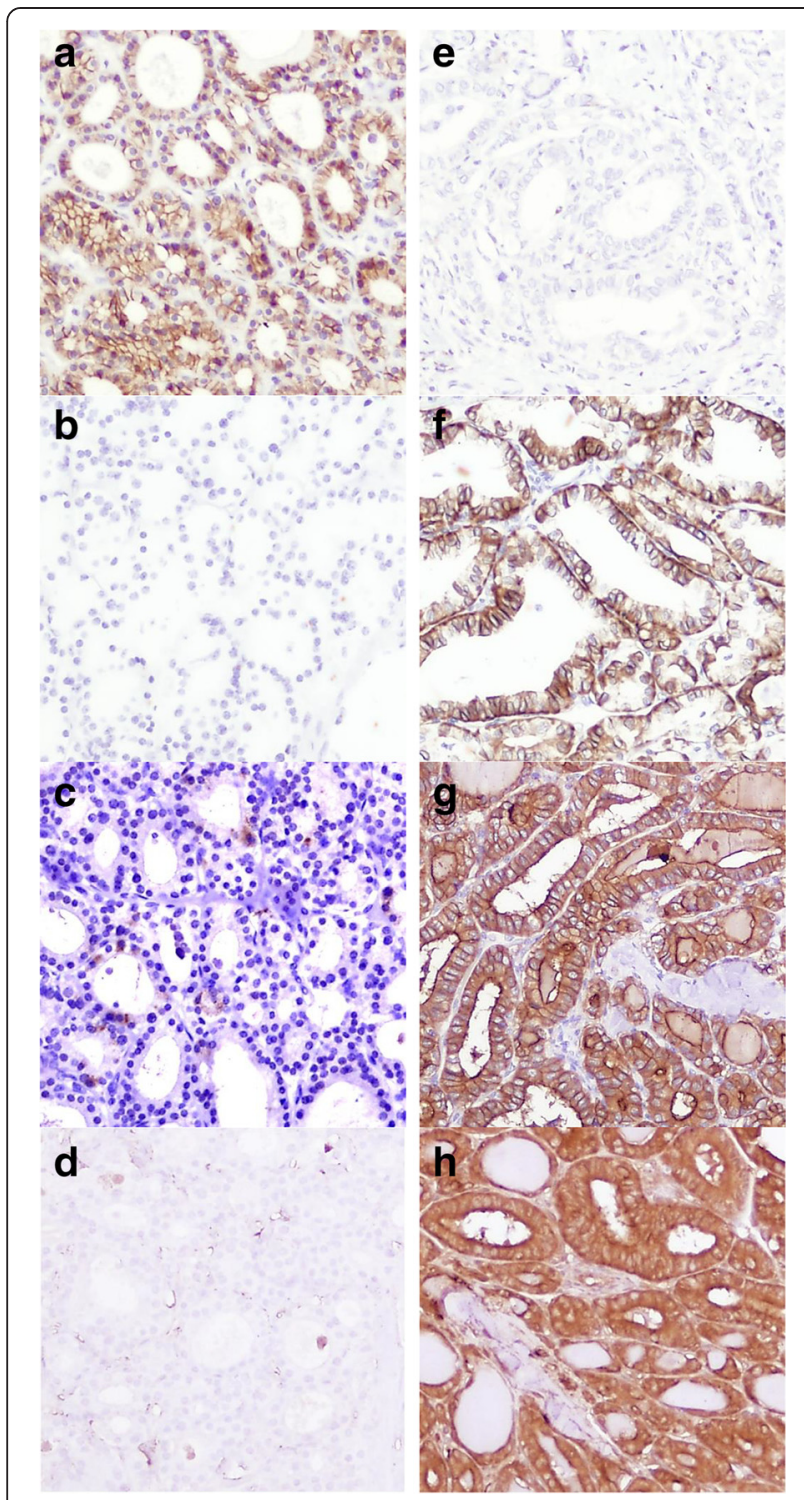

Fig. 1 Expression of CD56, CK19, HBME-1, Galectin-3 in folicular adenoma and follicular variant of papillary carcinoma. a membranous immunoexpression of CD56 in follicular adenoma; (b): absence of immunoexpression of CK19 in follicular adenoma; (c): absence of immunoexpression of HBME-1 in follicular adenoma; (d): absence of imunoexpression of Galectin-3 in follicular adenoma; (e): loss of immunoexpression of CD56 in follicular variant of papillary thyroid carcinoma; (f): membranous and cytoplasmatic immunoexpression of CK 19 in follicular variant of papillary thyroid carcinoma; (g): membranous and cytoplasmatic immunoexpression of HBME-1 in follicular variant of papillary thyroid carcinoma; (h): cytoplasmatic immunoexpression of Galectin-3 in follicular variant of papillary thyroid carcinoma

provides answers to questions asked in introductory part of this paper. We provided the readers with extensive review of literature on the subject, with fast insights in methodological approach, cut off values and results of reviewed studies.
All analysed immunomarkers may make a difference between benign lesions/tumours from differentiated thyroid carcinomas. CK19 and HBME-1 can differentiate between papillary carcinoma and follicular carcinoma. Expression of all markers is significantly higher in papillary carcinoma than in follicular adenoma. Galectin-3 could not distinct papillary from follicular carcinoma. CD56 and Galectin-3 could not differentiate between follicular variant of papillary carcinoma and follicular carcinoma. Interestingly, Galectin-3 and CD56 made statistically significant difference between follicular carcinoma and follicular adenoma. The only marker which makes statistically significant difference between adenoma and carcinoma of Hurthle cells was Galectin 3. Best balanced marker in our study, in terms of sensitivity and specificity for malignancy, was HBME-1. The most sensitive marker was Galectin 3, and the most specific marker in our study was CD56. Former mentioned marker, at the same time, had the lowest specificity, and latter had the lowest sensitivity of all. When we combined two, three or four co-expressed markers, we did not reach specificity of $100 \%$ for malignancy, nonetheless values increased compared to single marker expression. On the other hand, the unfavourable result was lowering of sensitivity for malignancy, compared with use of single marker. The best combination of coexpressing markers for identifying malignancy was HBME-1 and Gal-3. Best discriminatory combinations of markers for papillary carcinoma from follicular adenoma, and non-neoplastic lesions were CD56 with Galectin 3, and CK19 with Galectin 3, respectively. For discriminating follicular variant of papillary carcinoma from follicular adenoma or carcinoma, best combinations were CK19 with Galectin 3, and CD56 with HBME1, respectively.

Cytokeratin 19 is the smallest member of cytokeratins family, a heterogeneous group of intermediate filaments. Physiologically, it is expressed in simple and glandular epithelia, basal layer of stratified epithelium, and in hair follicles [12]. Healthy thyroid follicular cells do not produce this protein, and upregulation of CK19 is connected with neoplastic transformation. Strong and diffuse immunoreactivity of CK19 is most often related to papillary thyroid carcinoma [13].

Our result show that CK19 is overexpressed in papillary thyroid carcinoma, diffusely and intensively in most cases. Overexpression of this marker is related not just to PTC, but to malignancy. Discouraging thing, is that serious number of benign cases also expressed CK19, although focally and weakly. Only hyperplastic adenomas were completely negative in our investigation.

We reviewed 23 papers [10, 11, 14-34], and than recalculated average sensitivity and specificity for carcinomas ( $80 \%, 78 \%$ respectively). The results of our study 


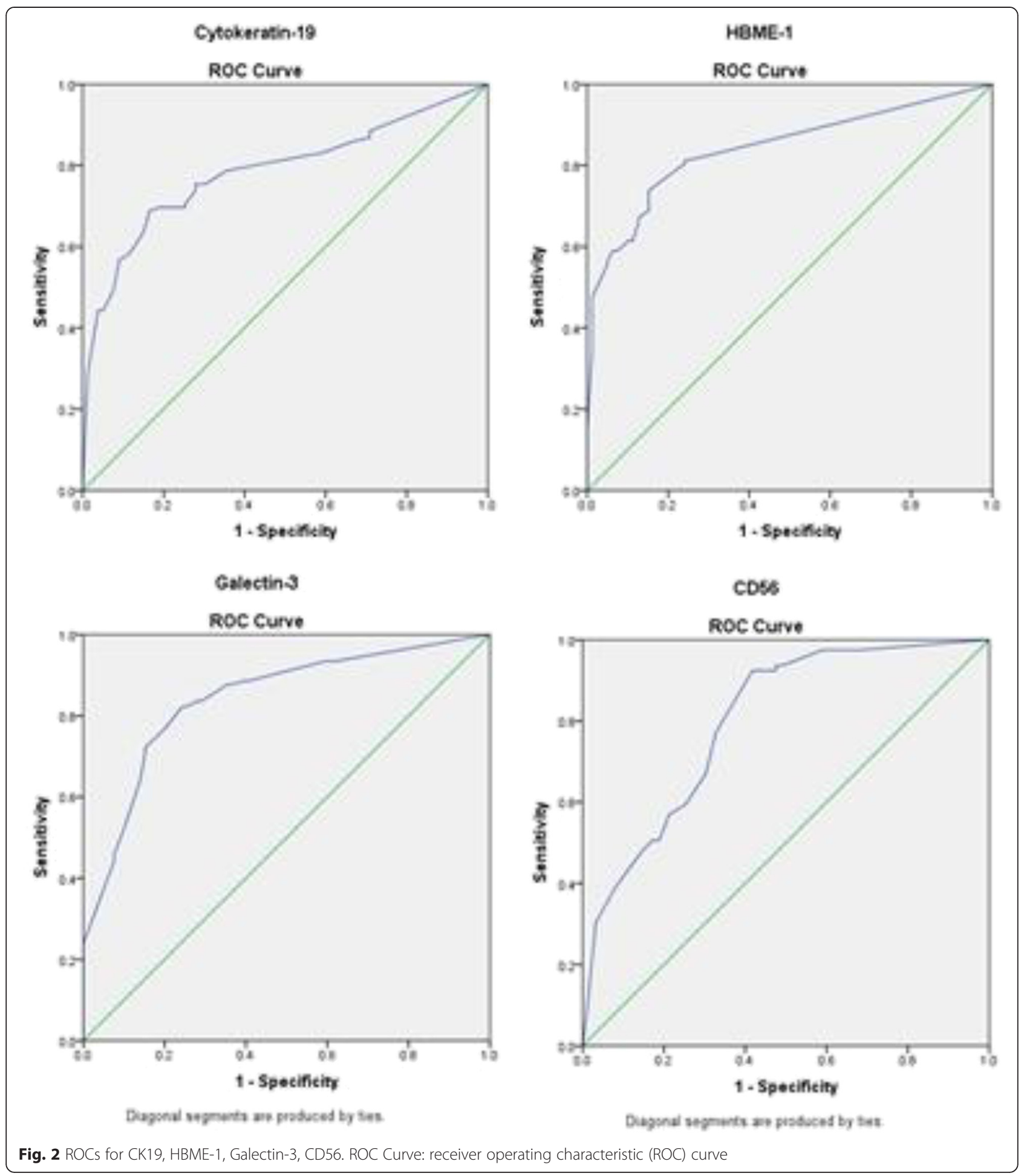

are in concordance with the results from majority of papers we have reviewed. Sensitivity values varied from 13 to $100 \%\left(\operatorname{median}_{\text {sens }}=84 \%\right)$, while specificity values varied from 0 to $100 \%\left(\right.$ median $_{\text {spec }}=75 \%$ ) (see Table 9). Control group non tumor tissues, follicular adenoma, follicular carcinoma, and papillary carcinoma had positive expression of this marker which varied from study to study: $4-89 \%$ (median $=20 \%$ ); 0-100 \% (me$\operatorname{dian}=24 \%) ; 0-50 \%($ median $=40 \%) ; 46-100 \%($ median $=95 \%)$, respectively.

Generally, studies showed that CK19 is more expressed in malignant lesions than in benign follicular cells derived 
Table 4 Area under the curve

\begin{tabular}{llllll}
\hline $\begin{array}{l}\text { Test Result } \\
\text { Variable(s): }\end{array}$ & Area & $\begin{array}{l}\text { Std. } \\
\text { Error }^{\mathrm{a}}\end{array}$ & $\begin{array}{l}\text { Asymptotic } \\
\text { Sig. }\end{array}$ & \multicolumn{2}{l}{ Asymptotic 95 \% Confidence Interval } \\
\cline { 5 - 6 } CK19 & .786 & .032 & .000 & .723 & Upper Bound \\
HBME-1 & .842 & .028 & .000 & .788 & .848 \\
Galectin-3 & .841 & .028 & .000 & .786 & .896 \\
CD56 & .799 & .031 & .000 & .739 & .860 \\
\hline
\end{tabular}

ander the nonparametric assumption

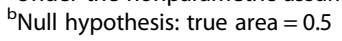

thyroid lesions $[14,15]$. The expression of CK19 in papillary carcinoma (general) and follicular variant PTC was significantly higher than in follicular thyroid carcinoma (FTC) [15]. Further, it can serve to differentiate papillary thyroid carcinoma from follicular adenoma [31], but can not help in differentiation between follicular adenoma and follicular carcinoma [30, 10]. Also, it does not make difference between follicular carcinoma and normal tissue [26].

In the end, we may make few conclusions: CK19 can help in diagnosis of papillary thyroid carcinoma, but one must take into account the intensity and distribution of marker within the tumour; CK19 intensive immunoreactivity, plus missing criteria for PTC, should alert on possibility of malignancy; due to its relatively low specificity, we recommend the use of marker in combination with others.

HBME1 (Hector Battifora Mesothelial 1), is monoclonal antibody which reacts with uncharacterized antibody in microvilli of mesothelial cells. HBME-1 has been assessed in thyroid with the aim to help in differentiation of benign from malignant lesions.

HBME-1 is more expressed in malignant lesions compared to benign lesions [10, 14, 15, 18, 23, 25, 32, 35]. Benign lesions expressed HBME-1 focally, rather than diffusely. It is more extensively expressed in papillary carcinomas compared to follicular carcinomas and follicular adenomas $[18,25]$. Follicular variant of papillary carcinoma has significantly higher expression of this marker than follicular adenoma or follicular carcinoma $[25,31]$.

Table 5 Diagnostic value of tests in discrimination of malignant from benign thyroid lesions

\begin{tabular}{lllll}
\hline For malignancy & HBME-1 & Galectin-3 & CK19 & CD56 \\
\hline Sensitivity & $71.31 \%$ & $88.52 \%$ & $75.41 \%$ & $58.20 \%$ \\
Specificity & $84.81 \%$ & $64.56 \%$ & $70.89 \%$ & $92.41 \%$ \\
Positive Likelihood Ratio & 4.69 & 2.5 & 2.59 & 7.66 \\
Negative Likelihood Ratio & 0.34 & 0.18 & 0.35 & 0.45 \\
Disease prevalence & $60.70 \%$ & $60.70 \%$ & $60.70 \%$ & $60.70 \%$ \\
Positive Predictive Value & $87.88 \%$ & $79.41 \%$ & $80.00 \%$ & $92.21 \%$ \\
Negative Predictive Value & $65.69 \%$ & $78.46 \%$ & $65.12 \%$ & $58.87 \%$ \\
Odds ratio & 13.8786 & 14.051 & 7.4667 & 16.9379 \\
\hline
\end{tabular}

The aforementioned studies and their results are in concordance with our study. The results of a few other studies were showing higher expression of HBME-1 in follicular carcinoma than in follicular adenoma. [10, 27, 32, 35], which is not the case with results of our study and some other studies [15, 25, 31]. When we pulled out all the results of expression of HBME-1 in follicular adenomas and follicular carcinomas from reviewed studies, and made comparison of those two groups, we have obtained significant difference in expression between two above mentioned groups (Fisher's exact test, the two-tailed $P$ value is less than 0.0001).

Among 25 reviewed studies [10, 11, 14-19, 22-25, $27,28,31,32,34-42]$, the sensitivity and specificity of this marker varied markedly (34-100 \% for sensitivity, 54-100 \% for specificity), with average sensitivity of $76 \%$ and specificity of $87 \%$ for carcinomas compared to benign lesions $\left(\operatorname{median}_{\text {sens }}=77 \%\right.$; $\operatorname{median}_{\text {spec }}=$ $89 \%)$. Control non tumor tissues showed positive expression of this marker in the range $0-35 \%$ (median = $10 \%)$ of cases. Follicular adenomas, follicular carcinomas and papillary carcinomas through the studies show positive expression in given ranges: $0-56 \%$ (me$\operatorname{dian}=25 \%) ; 17-100 \%$ (median $=65 \%) ; 55-100 \%$ (median $=92 \%)$, respectively. The increasing trend of expression is noticeable, starting from non-tumour tissues to papillary carcinomas.

Simultaneous immunopositivity for HBME-1 and Galectin 3, and HBME-1 and CK19 in the diagnosis of differentiated thyroid carcinoma have sensitivities of $85,9 \%$, and $86.4 \%$ respectively, and specificities of $100 \%$ for both combinations. Specificities values increased, but sensitivities values decreased comparing to single markers values [10].

Co-expression of HBME1 and CK19 has a sensitivity of $83 \%$ and specificity of $100 \%$ of diagnosing papillary carcinoma compared to follicular adenoma. Opposite, the HBME1-CK19 negative staining for both markers was highly indicative of follicular adenoma ( $99 \%$ specificity and $82 \%$ sensitivity) [16].

The combined use of HBME-1 and Gal-3 was able to improve sensitivity up to $99 \%$ and specificity up to $80 \%$ in diagnosis of malignant Hurthle cell tumours compared to Hurthle cell adenomas [41]. 
Table 6 Diagnostic value of markers combinations (all markers in combination positive) in discrimination of malignant from benign thyroid lesions

\begin{tabular}{|c|c|c|c|c|c|c|c|c|c|c|c|}
\hline For malignancy & CD56\&CK19 & CD56\&HBME1 & CD56\&Gal3 & CK19\&HBME1 & $\begin{array}{l}\text { CK19\&Gal } \\
3\end{array}$ & $\begin{array}{l}\text { HBME1\&Gal } \\
3\end{array}$ & $\begin{array}{l}\text { CD56\&Gal } \\
\text { 3\&CK19 }\end{array}$ & $\begin{array}{l}\text { HBME- } \\
1 \& \text { Gale3\&CK19 }\end{array}$ & $\begin{array}{l}\text { CD56\&Gal } \\
\text { 3\&HBME-1 }\end{array}$ & $\begin{array}{l}\text { CD56\&CK19\&HBME- } \\
1\end{array}$ & $\begin{array}{l}\text { CD56\&CK19\&HBME- } \\
\text { 1\&Gal } 3\end{array}$ \\
\hline Sensitivity & $50.82 \%$ & $50.00 \%$ & $52.46 \%$ & $60.66 \%$ & $68.03 \%$ & $64.75 \%$ & $45.90 \%$ & $54.92 \%$ & $45.08 \%$ & $45.08 \%$ & $40.16 \%$ \\
\hline Specificity & $94.94 \%$ & $98.73 \%$ & $97.47 \%$ & $89.87 \%$ & $88.61 \%$ & $92.41 \%$ & $97.47 \%$ & $93.67 \%$ & $98.73 \%$ & $98.73 \%$ & $98.73 \%$ \\
\hline $\begin{array}{l}\text { Positive Likelihood } \\
\text { Ratio }\end{array}$ & 10.04 & 39.5 & 20.72 & 5.99 & 5.97 & 8.53 & 18.13 & 8.68 & 35.61 & 35.61 & 31.73 \\
\hline $\begin{array}{l}\text { Negative } \\
\text { Likelihood Ratio }\end{array}$ & 0.52 & 0.51 & 0.49 & 0.44 & 0.36 & 0.38 & 0.56 & 0.48 & 0.56 & 0.56 & 0.61 \\
\hline Disease prevalence & $60.70 \%$ & $60.70 \%$ & $60.70 \%$ & $60.70 \%$ & $60.70 \%$ & $60.70 \%$ & $60.70 \%$ & $60.70 \%$ & $60.70 \%$ & $60.70 \%$ & $60.70 \%$ \\
\hline $\begin{array}{l}\text { Positive Predictive } \\
\text { Value }\end{array}$ & $93.94 \%$ & $98.39 \%$ & $96.97 \%$ & $90.24 \%$ & $90.22 \%$ & $92.94 \%$ & $96.55 \%$ & $93.06 \%$ & $98.21 \%$ & $98.21 \%$ & $98.00 \%$ \\
\hline $\begin{array}{l}\text { Negative Predictive } \\
\text { Value }\end{array}$ & $55.56 \%$ & $56.12 \%$ & $57.04 \%$ & $59.66 \%$ & $64.22 \%$ & $62.93 \%$ & $53.85 \%$ & $57.36 \%$ & $53.79 \%$ & $53.79 \%$ & $51.66 \%$ \\
\hline
\end{tabular}


Table 7 Sensitivity and specificity values of different markers combinations for different combinations of PH entities

\begin{tabular}{|c|c|c|c|c|c|c|c|c|}
\hline \multicolumn{2}{|c|}{$\begin{array}{l}\text { All markers in combination were positive } \\
\text { Sensitivity \& Specificity for first in comparison }\end{array}$} & \multirow{2}{*}{$\begin{array}{l}\text { Malign Benign } \\
50.8 \%\end{array}$} & \multirow{2}{*}{$\begin{array}{l}\text { PTC vs FA } \\
65.5 \%\end{array}$} & \multirow{2}{*}{$\begin{array}{l}\text { FVPTC vs FA } \\
50.0 \%\end{array}$} & \multirow{2}{*}{$\begin{array}{l}\text { FVPTC Vs FTC } \\
50.0 \%\end{array}$} & \multirow{2}{*}{$\begin{array}{l}\text { FTC vs FA } \\
20.0 \%\end{array}$} & \multirow{2}{*}{$\begin{array}{l}\text { PTC vs non-tumor } \\
65.5 \%\end{array}$} & \multirow{2}{*}{$\begin{array}{l}\text { HCC vs HCA } \\
10.0 \%\end{array}$} \\
\hline CD56_CK19 & Sensitivity & & & & & & & \\
\hline & Specificity & $94.9 \%$ & $100 \%$ & $100.0 \%$ & $85.7 \%$ & $100.0 \%$ & $92.9 \%$ & $90.0 \%$ \\
\hline \multirow[t]{2}{*}{ CD56_HBME1 } & Sensitivity & $50.0 \%$ & $65.5 \%$ & $55.0 \%$ & $55.0 \%$ & $13.3 \%$ & $65.5 \%$ & $10.0 \%$ \\
\hline & Specificity & $98.7 \%$ & $100 \%$ & $100.0 \%$ & $92.9 \%$ & $100.0 \%$ & $100.0 \%$ & $90.0 \%$ \\
\hline \multirow[t]{2}{*}{ CD56_GAL3 } & Sensitivity & $52.5 \%$ & $69 \%$ & $57.5 \%$ & $57.5 \%$ & $20.0 \%$ & $69.0 \%$ & $5.0 \%$ \\
\hline & Specificity & $97.5 \%$ & $100 \%$ & $100.0 \%$ & $85.7 \%$ & $100.0 \%$ & $97.6 \%$ & $90.0 \%$ \\
\hline \multirow[t]{2}{*}{ HBME1_CK19 } & Sensitivity & $60.7 \%$ & $67.8 \%$ & $52.5 \%$ & $52.5 \%$ & $20.0 \%$ & $67.8 \%$ & $60.0 \%$ \\
\hline & Specificity & $89.9 \%$ & $92.6 \%$ & $92.6 \%$ & $85.7 \%$ & $92.6 \%$ & $97.6 \%$ & $50.0 \%$ \\
\hline \multirow[t]{2}{*}{ GAL3_HBME1 } & Sensitivity & $64.8 \%$ & $70.1 \%$ & $60.0 \%$ & $60.0 \%$ & $20.0 \%$ & $70.1 \%$ & $75.0 \%$ \\
\hline & Specificity & $92.4 \%$ & $96.3 \%$ & $96.3 \%$ & $85.7 \%$ & $96.3 \%$ & $97.6 \%$ & $60.0 \%$ \\
\hline \multirow[t]{2}{*}{ CK19_GAL3 } & Sensitivity & $68.0 \%$ & $78.2 \%$ & $70.0 \%$ & $70.0 \%$ & $33.3 \%$ & $78.2 \%$ & $50.0 \%$ \\
\hline & Specificity & $88.6 \%$ & $88.9 \%$ & $88.9 \%$ & $71.4 \%$ & $88.9 \%$ & $92.9 \%$ & $70.0 \%$ \\
\hline \multirow[t]{2}{*}{ CD56_CK19_HBME1 } & Sensitivity & $45.1 \%$ & $58.6 \%$ & $45.0 \%$ & $45.0 \%$ & $13.3 \%$ & $58.6 \%$ & $10.0 \%$ \\
\hline & Specificity & $98.7 \%$ & $100 \%$ & $100.0 \%$ & $92.9 \%$ & $100.0 \%$ & $100.0 \%$ & $90.0 \%$ \\
\hline \multirow[t]{2}{*}{ CD56_GAL3_HBME1 } & Sensitivity & $45.1 \%$ & $59.8 \%$ & $50.0 \%$ & $50.0 \%$ & $13.3 \%$ & $59.8 \%$ & $5.0 \%$ \\
\hline & Specificity & $98.7 \%$ & $100 \%$ & $100.0 \%$ & $92.9 \%$ & $100.0 \%$ & $100.0 \%$ & $90.0 \%$ \\
\hline \multirow[t]{2}{*}{ CD56_GAL3_CK19 } & Sensitivity & $45.9 \%$ & $59.8 \%$ & $45.0 \%$ & $45.0 \%$ & $20.0 \%$ & $59.8 \%$ & $5.0 \%$ \\
\hline & Specificity & $97.5 \%$ & $100 \%$ & $100.0 \%$ & $85.7 \%$ & $100.0 \%$ & $97.6 \%$ & $90.0 \%$ \\
\hline \multirow[t]{2}{*}{ HBME1_GAL3_CK19 } & Sensitivity & $54.9 \%$ & $62.1 \%$ & $47.5 \%$ & $47.5 \%$ & $20.0 \%$ & $62.1 \%$ & $50.0 \%$ \\
\hline & Specificity & $93.7 \%$ & $96.3 \%$ & $96.3 \%$ & $85.7 \%$ & $96.3 \%$ & $97.6 \%$ & $70.0 \%$ \\
\hline \multirow[t]{2}{*}{ CD56_HBME1_GAL3_CK19 } & Sensitivity & $40.2 \%$ & $52.9 \%$ & $40.0 \%$ & $40.0 \%$ & $13.3 \%$ & $52.9 \%$ & $5.0 \%$ \\
\hline & Specificity & $98.7 \%$ & $100 \%$ & $100.0 \%$ & $92.9 \%$ & $100.0 \%$ & $100.0 \%$ & $90.0 \%$ \\
\hline
\end{tabular}

FA follicular adenoma, HA Hurthle cell adenoma, FTC follicular thyroid carcinoma, HCC Hurthle cell carcinoma, FVPTC folicular variant of papillary thyroid carcinoma, non-tumor (hyperplastic and colloid adenomas)

Galectin 3 is a structurally unique member $(31-\mathrm{kDa})$ of galectins family. Galectin-3 is capable to make cross links with cell membrane glycoproteins, thus forming new network involved in cellular signaling and receptors endocytosis. Galectin 3 is detected in nucleus, cytoplasm and in extra cellular space. Galectin 3 plays roles in apoptosis regulation, cell motility, and it is involved in thyroid carcinoma progression [43, 44].

Long ago, $\mathrm{Xu}$ et al. [44], had been investigating expression of Galectin 1 and Galectin 3 in small series of thyroid tumours, and they had found expression in papillary and follicular carcinomas, but not in adenomas, nodular goiter, nor in normal thyroid tissue. On

Table 8 Number of studies, patients and their distributions included in each analysis by the immunohistochemistry technique

\begin{tabular}{lllllll}
\hline & Studies & Patients & TP & FP & FN & TN \\
\hline CK19 & 24 & 4239 & 1834 & 436 & 464 & 1505 \\
CD56 & 10 & 1226 & 158 & 418 & 619 & 31 \\
HMBE-1 & 26 & 4691 & 1824 & 311 & 563 & 1993 \\
GALECT 3 & 38 & 5426 & 2344 & 442 & 458 & 2182 \\
\hline
\end{tabular}

the grounds of those investigations they deduced that galectins could bu useful in making distinction between benign and malignant thyroid tumours [44].

Expression of Galectin 3 is higher in malignant compared to benign thyroid lesions [10, 14, 15, 18, 23, 25, 35]. Some authors found difference in expression of Galectin 3 between papillary carcinoma, and its follicular variant, compared to follicular carcinoma [10, 25, 31]. Nevertheless, others have not found those differences, including here the results of our study too [15, 35]. Galectin 3 have been found to have higher immunoreactivity in papillary (also follicular variant) carcinoma compared to follicular adenoma [15, 25, 27, 31,35], which is comparable to our results. Few studies, including the current, found difference in expression of Galectin 3 between follicular carcinoma and follicular adenoma [10,35]. Galectin 3 was the only marker able to make a difference between Hurthle cell carcinoma and adenoma, which is also confirmed by the study of Volante M et al. [41].

Having made insight in data from reviewed studies [15-19, 23-32, 35, 36, 41, 45-60], once again, we have noticed high variability in sensitivity and specificity for carcinoma of this marker. The values of sensitivity have 
Table 9 Sensitivity and specificity of CK 19 for malignancy, plus total number and percent of cases with positive immunoexpression

\begin{tabular}{|c|c|c|c|c|c|c|c|c|c|c|c|c|c|c|c|c|c|c|c|c|c|c|c|c|c|}
\hline \multirow[t]{2}{*}{ Reference } & \multicolumn{2}{|c|}{ Benign } & \multicolumn{2}{|c|}{ Malignant } & \multirow{2}{*}{$\begin{array}{l}\text { NG } \\
\mathrm{N}\end{array}$} & \multirow[b]{2}{*}{$\%$} & \multirow{2}{*}{$\begin{array}{l}\text { FA } \\
N\end{array}$} & \multirow[b]{2}{*}{$\%$} & \multicolumn{2}{|l|}{$\mathrm{HA}$} & \multicolumn{2}{|c|}{$\mathrm{HCA}$} & \multicolumn{2}{|l|}{ FTC } & \multicolumn{2}{|l|}{ PTC } & \multicolumn{2}{|c|}{$\mathrm{HCC}$} & \multicolumn{2}{|c|}{ FVPTC } & \multirow[t]{2}{*}{ Sens } & \multirow[t]{2}{*}{ Spec } & \multirow[t]{2}{*}{ Cut off } & \multirow[t]{2}{*}{ TMA } & \multirow[t]{2}{*}{ Total } \\
\hline & $\mathrm{N}$ & $\%$ & $\mathrm{~N}$ & $\%$ & & & & & N & $\%$ & $\mathrm{~N}$ & $\%$ & $\mathrm{~N}$ & $\%$ & $\mathrm{~N}$ & $\%$ & N & $\%$ & $\mathrm{~N}$ & $\%$ & & & & & \\
\hline Dunđerović (2015) & 79 & $29 \%$ & 122 & $75 \%$ & 30 & $37 \%$ & 27 & $22 \%$ & 12 & $0 \%$ & 10 & $60 \%$ & 15 & $33 \%$ & 87 & $86 \%$ & 20 & $60 \%$ & 40 & $78 \%$ & $75 \%$ & $71 \%$ & $10 \%$ & yes & 201 \\
\hline Barroeta (2006) [14] & 53 & $34 \%$ & 37 & $70 \%$ & 4 & $25 \%$ & 3 & $0 \%$ & 18 & $17 \%$ & 3 & $0 \%$ & 7 & $43 \%$ & 11 & $91 \%$ & 4 & $25 \%$ & 4 & $100 \%$ & $70 \%$ & $66 \%$ & $25 \%$ & yes & 90 \\
\hline Zhu X (2010) [15] & 58 & $26 \%$ & 180 & $79 \%$ & 17 & $12 \%$ & 21 & $14 \%$ & & & & & 11 & $27 \%$ & 155 & $87 \%$ & & & 7 & $86 \%$ & $79 \%$ & $74 \%$ & $5 \%$ & no & 238 \\
\hline Park YJ (2007) [10] & 89 & $17 \%$ & 206 & $90 \%$ & 54 & $9 \%$ & 35 & $29 \%$ & & & & & 25 & $44 \%$ & 181 & $98 \%$ & & & 17 & $100 \%$ & $90 \%$ & $83 \%$ & $10 \%$ & no & 295 \\
\hline Scognamiglio(2006) [16] & 49 & $14 \%$ & 78 & $96 \%$ & & & 49 & $14 \%$ & & & & & & & 78 & $96 \%$ & & & 29 & $90 \%$ & $96 \%$ & $86 \%$ & $10 \%$ & yes & 127 \\
\hline Nasr MR (2006) [17] & 57 & $68 \%$ & 51 & $100 \%$ & 37 & $75 \%$ & 6 & $83 \%$ & 14 & $43 \%$ & & & & & 51 & $100 \%$ & & & 10 & $100 \%$ & $100 \%$ & $32 \%$ & $10 \%$ & no & 108 \\
\hline Prasad ML (2005) [18] & 123 & $11 \%$ & 85 & $66 \%$ & 88 & $15 \%$ & 19 & $10 \%$ & 14 & $0 \%$ & 2 & $0 \%$ & 6 & $50 \%$ & 67 & $72 \%$ & 8 & $50 \%$ & 13 & $79 \%$ & $66 \%$ & $89 \%$ & $10 \%$ & no & 208 \\
\hline Casey MB (2003) [19] & 30 & $40 \%$ & 30 & $100 \%$ & & & & & 30 & $40 \%$ & & & & & 30 & $100 \%$ & & & & & $100 \%$ & $60 \%$ & $>0 \%$ & no & 60 \\
\hline Erkilic S (2002) [20] & 40 & $28 \%$ & 25 & $100 \%$ & 25 & $20 \%$ & 15 & $40 \%$ & & & & & & & 25 & $100 \%$ & & & & & $100 \%$ & $73 \%$ & NA & no & 65 \\
\hline Sahoo S (2001) [21] & 20 & $100 \%$ & 15 & $100 \%$ & & & 20 & $100 \%$ & & & & & & & 15 & $100 \%$ & & & 10 & $100 \%$ & $100 \%$ & $0 \%$ & NA & no & 35 \\
\hline Cheung CC (2001) [22] & 75 & $20 \%$ & 157 & $61 \%$ & 40 & $20 \%$ & 35 & $3 \%$ & & & & & 4 & $0 \%$ & 138 & $66 \%$ & 7 & $29 \%$ & 84 & $57 \%$ & $61 \%$ & $80 \%$ & NA & no & 232 \\
\hline Barut F (2010) [23] & 393 & $22 \%$ & 65 & $92 \%$ & & & 22 & $50 \%$ & 283 & $0 \%$ & 8 & $50 \%$ & 10 & $50 \%$ & 55 & $100 \%$ & & & 14 & $100 \%$ & $92 \%$ & $78 \%$ & $10 \%$ & no & 458 \\
\hline Wiseman SM (2008) [24] & 100 & $46 \%$ & 105 & $95 \%$ & & & & & & & & & & & & & & & & & $95 \%$ & $54 \%$ & NA & yes & 205 \\
\hline Liu YY (2008) [25] & 100 & $3 \%$ & 77 & $56 \%$ & 64 & $4 \%$ & 12 & $0 \%$ & & & & & 13 & $0 \%$ & 53 & $78 \%$ & & & 11 & $22 \%$ & $56 \%$ & $98 \%$ & other & yes & 177 \\
\hline Murphy K (2008) [26] & 45 & $47 \%$ & 43 & $65 \%$ & 19 & $89 \%$ & 15 & $27 \%$ & & & & & 14 & $43 \%$ & 29 & $76 \%$ & & & 9 & $22 \%$ & $65 \%$ & $54 \%$ & $>0 \%$ & yes & 88 \\
\hline Nakamura N (2006) [27] & 32 & $44 \%$ & 130 & $81 \%$ & 5 & $40 \%$ & 27 & $44 \%$ & & & & & 21 & $38 \%$ & 94 & $94 \%$ & & & 45 & $91 \%$ & $81 \%$ & $56 \%$ & $10 \%$ & yes & 162 \\
\hline Rossi ED (2006) [28] & 58 & $3 \%$ & 42 & $86 \%$ & & & 17 & $2 \%$ & 41 & $2 \%$ & & & & & 42 & $86 \%$ & & & 28 & $82 \%$ & $86 \%$ & $97 \%$ & NA & no & 100 \\
\hline Song Q (2011) [29] & 151 & $26 \%$ & 441 & $96 \%$ & 97 & $26 \%$ & 54 & $24 \%$ & & & & & & & 441 & $96 \%$ & & & & & $96 \%$ & $74 \%$ & $10 \%$ & no & 592 \\
\hline Beesley MF (2002) [30] & 28 & $25 \%$ & 41 & $83 \%$ & 8 & $25 \%$ & 20 & $25 \%$ & & & & & 12 & $41 \%$ & 26 & $100 \%$ & & & & & $83 \%$ & $75 \%$ & $>0 \%$ & no & 69 \\
\hline de Matos PS (2005) [31] & 210 & $7 \%$ & 129 & $54 \%$ & 170 & $0 \%$ & 18 & $33 \%$ & 12 & $17 \%$ & & & 38 & $21 \%$ & 84 & $73 \%$ & & & 25 & $52 \%$ & $54 \%$ & $93 \%$ & $>0 \%$ & no & 339 \\
\hline Nechifor-Boilă A (2014) [1 1] & 11 & $0 \%$ & 11 & $45 \%$ & 3 & $0 \%$ & 5 & $0 \%$ & & & & & & & 11 & $46 \%$ & & & 5 & $0 \%$ & $45 \%$ & $100 \%$ & $10 \%$ & yes & 22 \\
\hline Jang MH (2015) [32] & 113 & $6 \%$ & 79 & $13 \%$ & 41 & $7 \%$ & 72 & $6 \%$ & & & & & 79 & $13 \%$ & & & & & & & $13 \%$ & $94 \%$ & $10 \%$ & yes & 192 \\
\hline Yassin FE (2015) [33] & 18 & $33 \%$ & 24 & $100 \%$ & & & 8 & $25 \%$ & 4 & $0 \%$ & & & & & 24 & $100 \%$ & & & 6 & $100 \%$ & $100 \%$ & $67 \%$ & $>0 \%$ & no & 42 \\
\hline Choi YL (2005) [34] & 9 & $22 \%$ & 125 & $80 \%$ & 9 & $22 \%$ & & & & & & & 30 & $47 \%$ & 67 & $100 \%$ & 6 & $67 \%$ & & & $90 \%$ & $78 \%$ & $5 \%$ & no & 134 \\
\hline Total & 1941 & & 2298 & & 711 & & 500 & & 428 & & 23 & & 285 & & 1764 & & 45 & & 357 & & & & & & 4239 \\
\hline
\end{tabular}

NG/N nodular goiter/normal, FA follicular adenoma, HA hyperplastic adenoma, HCA Hurthle cell adenoma, FTC follicular thyroid carcinoma, HCC Hurthle cell carcinoma, FVPTC folicular variant of papillary thyroid 
Table 10 Sensitivity and specificity of HBME-1for malignancy, plus total number and percent of cases with positive immunoexpression

\begin{tabular}{|c|c|c|c|c|c|c|c|c|c|c|c|c|c|c|c|c|c|c|c|c|c|c|c|c|c|}
\hline \multirow[t]{2}{*}{ Reference } & \multicolumn{2}{|c|}{ Benign } & \multicolumn{2}{|c|}{ Malignant } & \multirow{2}{*}{$\begin{array}{l}\text { NG } \\
\mathrm{N}\end{array}$} & \multirow[b]{2}{*}{$\%$} & \multirow{2}{*}{$\begin{array}{l}\text { FA } \\
N\end{array}$} & \multirow[b]{2}{*}{$\%$} & \multirow{2}{*}{$\begin{array}{l}\mathrm{HA} \\
\mathrm{N}\end{array}$} & \multirow[b]{2}{*}{$\%$} & \multicolumn{2}{|c|}{ HCA } & \multicolumn{2}{|l|}{ FTC } & \multicolumn{2}{|l|}{ PTC } & \multicolumn{2}{|l|}{$\mathrm{HCC}$} & \multicolumn{2}{|c|}{ FVPTC } & \multirow[t]{2}{*}{ Sens } & \multirow[t]{2}{*}{ Spec } & \multirow[b]{2}{*}{ cut off } & \multirow[b]{2}{*}{ TMA } & \multirow[b]{2}{*}{ Total } \\
\hline & $\mathrm{N}$ & $\%$ & $\mathrm{~N}$ & $\%$ & & & & & & & N & $\%$ & N & $\%$ & N & $\%$ & N & $\%$ & N & $\%$ & & & & & \\
\hline Dunđerović (2015) & 79 & $15 \%$ & 122 & $71 \%$ & 30 & $3 \%$ & 27 & $15 \%$ & 12 & $0 \%$ & 10 & $70 \%$ & 15 & $27 \%$ & 87 & $76 \%$ & 20 & $85 \%$ & 40 & $65 \%$ & $71 \%$ & $85 \%$ & $10 \%$ & yes & 201 \\
\hline Barroeta (2006) [14] & 53 & $10 \%$ & 37 & $70 \%$ & 4 & $25 \%$ & 3 & $33 \%$ & 18 & $6 \%$ & 3 & $0 \%$ & 7 & $71 \%$ & 11 & $91 \%$ & 4 & $25 \%$ & 4 & $75 \%$ & $70 \%$ & $90 \%$ & $25 \%$ & yes & 90 \\
\hline Zhu X (2010) [15] & 58 & $47 \%$ & 180 & $92 \%$ & 17 & $35 \%$ & 21 & $52 \%$ & & & & & 11 & $82 \%$ & 155 & $95 \%$ & & & 7 & $100 \%$ & $92 \%$ & $54 \%$ & $5 \%$ & no & 238 \\
\hline Park YJ (2007) [10] & 89 & $32 \%$ & 206 & $91 \%$ & 54 & $20 \%$ & 35 & $49 \%$ & & & & & 25 & $88 \%$ & 181 & $92 \%$ & & & 17 & $94 \%$ & $91 \%$ & $69 \%$ & $10 \%$ & no & 295 \\
\hline Scognamiglio (2006) [16] & 49 & $4 \%$ & 78 & $87 \%$ & & & 49 & $4 \%$ & & & & & & & 78 & $87 \%$ & & & 29 & $86 \%$ & $87 \%$ & $96 \%$ & $10 \%$ & yes & 127 \\
\hline Nasr MR (2006) [17] & 57 & $7 \%$ & 51 & $96 \%$ & 37 & $11 \%$ & 6 & $0 \%$ & 14 & $0 \%$ & & & & & 51 & $96 \%$ & & & 10 & $90 \%$ & $96 \%$ & $93 \%$ & $10 \%$ & no & 108 \\
\hline Prasad ML (2005) [18] & 123 & $2 \%$ & 92 & $72 \%$ & 88 & $1 \%$ & 19 & $10 \%$ & 14 & $0 \%$ & 2 & $0 \%$ & 6 & $50 \%$ & 67 & $85 \%$ & 8 & $13 \%$ & 13 & $93 \%$ & $72 \%$ & $98 \%$ & $10 \%$ & no & 215 \\
\hline Casey MB (2003) [19] & 30 & $3 \%$ & 30 & $100 \%$ & & & & & 30 & $3 \%$ & & & & & 30 & $100 \%$ & & & & & $100 \%$ & $97 \%$ & $>0 \%$ & no & 60 \\
\hline Cheung CC (2001) [22] & 75 & $0 \%$ & 157 & $54 \%$ & 40 & $0 \%$ & 35 & $0 \%$ & & & & & 4 & $50 \%$ & 138 & $55 \%$ & 7 & $29 \%$ & 84 & $45 \%$ & $54 \%$ & $100 \%$ & ukn & no & 232 \\
\hline Barut F (2010) [23] & 393 & $5 \%$ & 65 & $97 \%$ & & & 22 & $50 \%$ & 283 & $1 \%$ & 8 & $25 \%$ & 10 & $90 \%$ & 55 & $98 \%$ & & & 14 & $100 \%$ & $97 \%$ & $95 \%$ & $10 \%$ & no & 458 \\
\hline Wiseman SM (2008) [24] & 100 & $5 \%$ & 105 & $54 \%$ & & & & & & & & & & & & & & & & & $54 \%$ & $95 \%$ & ukn & yes & 205 \\
\hline Liu YY (2008) [25] & 100 & $2 \%$ & 77 & $66 \%$ & 64 & $2 \%$ & 12 & $11 \%$ & & & & & 13 & $17 \%$ & 53 & $74 \%$ & & & 11 & $89 \%$ & $66 \%$ & $98 \%$ & other & yes & 177 \\
\hline Nakamura N (2006) [27] & 32 & $9 \%$ & 130 & $77 \%$ & 5 & $0 \%$ & 27 & $11 \%$ & & & & & 21 & $38 \%$ & 94 & $97 \%$ & & & 45 & $96 \%$ & $77 \%$ & $91 \%$ & $10 \%$ & yes & 162 \\
\hline Rossi ED (2006) [28] & 58 & $2 \%$ & 42 & $93 \%$ & & & 17 & $2 \%$ & 41 & $0 \%$ & & & & & 42 & $93 \%$ & & & 28 & $93 \%$ & $93 \%$ & $98 \%$ & ukn & no & 100 \\
\hline de Matos PS (2005) [31] & 210 & $11 \%$ & 129 & $80 \%$ & 170 & $0 \%$ & 18 & $56 \%$ & 12 & $33 \%$ & & & 38 & $63 \%$ & 84 & $94 \%$ & & & 25 & $84 \%$ & $80 \%$ & $89 \%$ & $>0 \%$ & no & 339 \\
\hline Nikiforova MN (2003) [36] & 23 & $13 \%$ & 33 & $34 \%$ & & & 23 & $13 \%$ & & & 13 & NA & 33 & $34 \%$ & & & 19 & NA & & & $34 \%$ & $87 \%$ & $10 \%$ & no & 56 \\
\hline Mai KT (2002) [37] & 93 & $14 \%$ & 96 & $71 \%$ & & & 45 & $42 \%$ & & & 48 & $8 \%$ & 29 & $65 \%$ & 55 & $85 \%$ & 12 & $0 \%$ & & & $71 \%$ & $86 \%$ & $>0 \%$ & no & 189 \\
\hline Liang HS (2009) [38] & 48 & $29 \%$ & 71 & $92 \%$ & & & 48 & $29 \%$ & & & & & 26 & $92 \%$ & 45 & $91 \%$ & & & & & $92 \%$ & $71 \%$ & $5 \%$ & yes & 119 \\
\hline Ito Y (2005) [39] & 253 & $26 \%$ & 175 & $69 \%$ & & & 155 & $30 \%$ & 98 & $17 \%$ & & & 138 & $61 \%$ & 37 & $100 \%$ & & & & & $69 \%$ & $74 \%$ & $>0 \%$ & no & 428 \\
\hline Mase T (2003) [40] & 124 & $20 \%$ & 81 & $84 \%$ & 62 & $13 \%$ & 62 & $27 \%$ & & & & & 39 & $85 \%$ & 36 & $97 \%$ & & & & & $84 \%$ & $80 \%$ & $25 \%$ & no & 205 \\
\hline Volante M (2004) [41] & 50 & $12 \%$ & 102 & $53 \%$ & & & & & & & 50 & $12 \%$ & & & 32 & $88 \%$ & 70 & $37 \%$ & & & $53 \%$ & $88 \%$ & $>0 \%$ & no & 152 \\
\hline Nechifor-Boilă A (2014) [11] & 11 & $27 \%$ & 11 & $64 \%$ & 3 & $33 \%$ & 5 & $40 \%$ & & & & & & & 11 & $64 \%$ & & & 5 & $60 \%$ & $64 \%$ & $73 \%$ & $10 \%$ & yes & 22 \\
\hline Jang MH (2015) [32] & 113 & $34 \%$ & 79 & $66 \%$ & 41 & $10 \%$ & 72 & $47 \%$ & & & & & 79 & $66 \%$ & & & & & & & $66 \%$ & $66 \%$ & $10 \%$ & yes & 192 \\
\hline Guo Z (2015) [42] & 52 & $0 \%$ & 85 & $77 \%$ & 20 & $0 \%$ & 32 & $0 \%$ & & & & & 28 & $40 \%$ & 57 & $96 \%$ & & & 29 & $92 \%$ & $77 \%$ & $100 \%$ & $>0 \%$ & yes & 137 \\
\hline Abd-El Raouf (2014) [35] & 22 & $23 \%$ & 28 & $89 \%$ & 13 & $23 \%$ & 9 & $22 \%$ & & & & & 5 & $80 \%$ & 23 & $91 \%$ & & & 5 & $80 \%$ & $89 \%$ & $77 \%$ & $10 \%$ & no & 50 \\
\hline Choi YL (2005) [34] & 9 & $33 \%$ & 125 & $90 \%$ & 9 & $33 \%$ & & & & & & & 30 & $100 \%$ & 67 & $97 \%$ & 6 & $67 \%$ & & & $90 \%$ & $67 \%$ & $5 \%$ & no & 134 \\
\hline Total & 2304 & & 2387 & & 657 & & 742 & & 522 & & 134 & & 557 & & 1489 & & 146 & & 366 & & $77 \%$ & $89 \%$ & & & 4691 \\
\hline
\end{tabular}

NG/N nodular goiter/normal, FA follicular adenoma, HA hyperplastic adenoma, HCA Hurthle cell adenoma, FTC follicular thyroid carcinoma, HCC Hurthle cell carcinoma, FVPTC folicular variant of papillary thyroid carcinoma, Sens sensitivity, Spec specificity, TMA tissue microarray, NA not available, ukn unknown 
Table 11 Sensitivity and specificity of Galectin 3 for malignancy, plus total number and percent of cases with positive immunoexpression

\begin{tabular}{|c|c|c|c|c|c|c|c|c|c|c|c|c|c|c|c|c|c|c|c|c|c|c|c|c|c|}
\hline \multirow[t]{2}{*}{ Reference } & \multicolumn{2}{|c|}{ Benign } & \multicolumn{2}{|c|}{ Malignant } & \multicolumn{2}{|l|}{ NG } & \multirow{2}{*}{$\begin{array}{l}\mathrm{FA} \\
\mathrm{N}\end{array}$} & \multirow[b]{2}{*}{$\%$} & \multicolumn{2}{|l|}{$\mathrm{HA}$} & \multicolumn{2}{|c|}{$\mathrm{HCA}$} & \multicolumn{2}{|l|}{ FTC } & \multicolumn{2}{|l|}{ PTC } & \multicolumn{2}{|c|}{$\mathrm{HCC}$} & \multicolumn{2}{|c|}{ FVPTC } & \multirow[b]{2}{*}{ Sens } & \multirow[b]{2}{*}{ Spec } & \multirow[b]{2}{*}{$\begin{array}{l}\text { Cut } \\
\text { off }\end{array}$} & \multirow[b]{2}{*}{ TMA } & \multirow[b]{2}{*}{ Total } \\
\hline & $\mathrm{N}$ & $\%$ & $\mathrm{~N}$ & $\%$ & N & $\%$ & & & N & $\%$ & $N$ & $\%$ & N & $\%$ & $N$ & $\%$ & N & $\%$ & $\mathrm{~N}$ & $\%$ & & & & & \\
\hline Dunđerović (2015) & 79 & $35 \%$ & 122 & $89 \%$ & 30 & $13 \%$ & 27 & $41 \%$ & 12 & $67 \%$ & 10 & $50 \%$ & 15 & $73 \%$ & 87 & $92 \%$ & 20 & $85 \%$ & 40 & $93 \%$ & $89 \%$ & $65 \%$ & $10 \%$ & Yes & 201 \\
\hline Barroeta et al. 2006 [14] & 53 & $34 \%$ & 37 & $73 \%$ & 4 & $0 \%$ & 3 & $0 \%$ & 18 & $6 \%$ & 3 & $33 \%$ & 7 & $57 \%$ & 11 & $82 \%$ & 4 & $75 \%$ & 4 & $75 \%$ & $73 \%$ & $66 \%$ & $25 \%$ & Yes & 90 \\
\hline Zhu X et al. 2010 [15] & 58 & $34 \%$ & 180 & $86 \%$ & 17 & $24 \%$ & 21 & $14 \%$ & & & & & 11 & $64 \%$ & 155 & $92 \%$ & & & & $100 \%$ & $86 \%$ & $66 \%$ & $5 \%$ & No & 238 \\
\hline Park YJ et al. 2007 [10] & 89 & $5 \%$ & 206 & $95 \%$ & 54 & $6 \%$ & 35 & $3 \%$ & & & & & 25 & $64 \%$ & 181 & $99 \%$ & & & 17 & $94 \%$ & $95 \%$ & $96 \%$ & $10 \%$ & No & 295 \\
\hline Scognamiglio (2006) [16] & 49 & $18 \%$ & 78 & $94 \%$ & & & 49 & $18 \%$ & & & & & & & 78 & $94 \%$ & & & 29 & $90 \%$ & $94 \%$ & $82 \%$ & $10 \%$ & Yes & 127 \\
\hline Prasad ML e (2005) [18] & 123 & $15 \%$ & 92 & $92 \%$ & 88 & $18 \%$ & 19 & $10 \%$ & 14 & $7 \%$ & 2 & $0 \%$ & 6 & $66 \%$ & 67 & $94 \%$ & 8 & $88 \%$ & 13 & $100 \%$ & $92 \%$ & $85 \%$ & $10 \%$ & No & 215 \\
\hline Casey MB (2003) [19] & 30 & $60 \%$ & 30 & $100 \%$ & & & & & 30 & $60 \%$ & & & & & 30 & $100 \%$ & & & & & $100 \%$ & $40 \%$ & $0 \%$ & No & 60 \\
\hline Barut F (2010) [23] & 393 & $4 \%$ & 65 & $94 \%$ & & & 22 & $36 \%$ & 283 & $0 \%$ & 8 & $25 \%$ & 10 & $90 \%$ & 55 & $95 \%$ & & & 14 & $98 \%$ & $94 \%$ & $96 \%$ & $10 \%$ & No & 458 \\
\hline Wiseman SM (2008) [24] & 100 & $23 \%$ & 105 & $87 \%$ & & & & & & & & & & & & & & & & & $87 \%$ & $77 \%$ & ukn & Yes & 205 \\
\hline Liu YY (2008) [25] & 100 & $6 \%$ & 77 & $71 \%$ & 64 & $10 \%$ & 12 & $0 \%$ & & & & & 13 & $33 \%$ & 53 & $92 \%$ & & & 11 & $33 \%$ & $71 \%$ & $94 \%$ & other & Yes & 177 \\
\hline Murphy K (2008) [26] & 45 & $42 \%$ & 43 & $65 \%$ & 19 & $42 \%$ & 15 & $33 \%$ & & & & & 14 & $21 \%$ & 29 & $86 \%$ & & & 9 & $55 \%$ & $65 \%$ & $58 \%$ & $>0 \%$ & Yes & 88 \\
\hline Nakamura N (2006) [27] & 32 & $25 \%$ & 130 & $88 \%$ & 5 & $0 \%$ & 27 & $30 \%$ & & & & & 21 & $48 \%$ & 94 & $96 \%$ & & & 45 & $98 \%$ & $88 \%$ & $75 \%$ & $10 \%$ & Yes & 162 \\
\hline Rossi ED (2006) [28] & 58 & $0 \%$ & 42 & $88 \%$ & & & 17 & $0 \%$ & 41 & $0 \%$ & & & & & 42 & $88 \%$ & & & 28 & $86 \%$ & $88 \%$ & $100 \%$ & ukn & No & 100 \\
\hline Song Q (2011) [29] & 151 & $51 \%$ & 441 & $97 \%$ & 97 & $52 \%$ & 54 & $48 \%$ & & & & & & & 441 & $97 \%$ & & & & & $97 \%$ & $49 \%$ & $10 \%$ & No & 592 \\
\hline Beesley MF (2002) [30] & 28 & $18 \%$ & 41 & $85 \%$ & 8 & $38 \%$ & 20 & $10 \%$ & & & & & 12 & $100 \%$ & 26 & $85 \%$ & & & & & $85 \%$ & $82 \%$ & $>0 \%$ & No & 69 \\
\hline de Matos PS (2005) [31] & 210 & $5 \%$ & 129 & $53 \%$ & 170 & $0 \%$ & 18 & $11 \%$ & 12 & $8 \%$ & & & 38 & $21 \%$ & 84 & $73 \%$ & & & 25 & $52 \%$ & $53 \%$ & $95 \%$ & $>0 \%$ & No & 339 \\
\hline Nikiforova MN (2003) [36] & 23 & $4 \%$ & 33 & $15 \%$ & & & 23 & $4 \%$ & & & & & 33 & $15 \%$ & & & & & & & $15 \%$ & $96 \%$ & $10 \%$ & No & 56 \\
\hline Inohara H (2008) [45] & 60 & $28 \%$ & 56 & $89 \%$ & 34 & $24 \%$ & 26 & $35 \%$ & & & & & 16 & $63 \%$ & 40 & $100 \%$ & & & & & $89 \%$ & $72 \%$ & $>0 \%$ & No & 116 \\
\hline Aiad HA (2008) [46] & 38 & $11 \%$ & 41 & $93 \%$ & 19 & $11 \%$ & 19 & $11 \%$ & & & & & 13 & $92 \%$ & 28 & $93 \%$ & & & & & $93 \%$ & $90 \%$ & $>0 \%$ & No & 79 \\
\hline Sapio MR (2007) [47] & 62 & $27 \%$ & 106 & $87 \%$ & 51 & $29 \%$ & 11 & $18 \%$ & & & & & 32 & $75 \%$ & 74 & $92 \%$ & & & 19 & $79 \%$ & $87 \%$ & $73 \%$ & $10 \%$ & No & 168 \\
\hline Galusca B (2005) [48] & 62 & $18 \%$ & 23 & $96 \%$ & 36 & $8 \%$ & 16 & $31 \%$ & & & 10 & $30 \%$ & 6 & $100 \%$ & 15 & $93 \%$ & & & & & $96 \%$ & $82 \%$ & $>0 \%$ & No & 85 \\
\hline Nucera C (2005) [49] & 105 & $11 \%$ & 28 & $68 \%$ & 20 & $0 \%$ & 22 & $45 \%$ & & & & & 6 & $66 \%$ & 15 & $80 \%$ & 4 & $75 \%$ & & & $68 \%$ & $90 \%$ & NA & NA & 133 \\
\hline Weber KB (2004) [50] & 13 & $31 \%$ & 33 & $79 \%$ & & & 13 & $31 \%$ & & & & & 9 & $44 \%$ & 24 & $92 \%$ & & & & & $79 \%$ & $69 \%$ & $5 \%$ & No & 46 \\
\hline $\begin{array}{l}\text { Oestreicher-Kedem (2004) } \\
\text { [70] }\end{array}$ & 25 & $28 \%$ & 29 & $75 \%$ & & & 19 & $11 \%$ & & & 6 & $83 \%$ & 11 & $63 \%$ & 18 & $83 \%$ & & & 18 & $83 \%$ & $75 \%$ & $72 \%$ & $5 \%$ & No & 54 \\
\hline Volante M (2004) [41] & 50 & $12 \%$ & 102 & $95 \%$ & & & & & & & 50 & $12 \%$ & & & 32 & $97 \%$ & 70 & $94 \%$ & & & $95 \%$ & $88 \%$ & $>0 \%$ & No & 152 \\
\hline Torres-Cabala C (2004) [51] & 91 & $9 \%$ & 60 & $77 \%$ & 57 & $0 \%$ & 12 & $17 \%$ & 14 & $0 \%$ & 3 & $33 \%$ & 13 & $62 \%$ & 34 & $91 \%$ & 4 & $100 \%$ & 12 & $92 \%$ & $77 \%$ & $91 \%$ & $>0 \%$ & No & 151 \\
\hline Lavra L (2011) [52] & 14 & $0 \%$ & 29 & $93 \%$ & & & & & 14 & $0 \%$ & & & 3 & $67 \%$ & 24 & $96 \%$ & 2 & $100 \%$ & 9 & $100 \%$ & $93 \%$ & $100 \%$ & ukn & No & 43 \\
\hline Kovacs RB (2003) [53] & 55 & $22 \%$ & 36 & $89 \%$ & 25 & $0 \%$ & 19 & $21 \%$ & 3 & $0 \%$ & & & 10 & $67 \%$ & 20 & $100 \%$ & & & & & $89 \%$ & $78 \%$ & $>0 \%$ & No & 91 \\
\hline Jakubiak-Wielganowiczv [54] & 42 & $19 \%$ & 42 & $86 \%$ & & & 42 & $19 \%$ & & & & & 17 & $71 \%$ & & & 25 & $96 \%$ & & & $86 \%$ & $81 \%$ & $>0 \%$ & No & 84 \\
\hline Giannini R (2003) [55] & 20 & $10 \%$ & 45 & $93 \%$ & & & 20 & $10 \%$ & & & & & & & 45 & $93 \%$ & & & & & $93 \%$ & $90 \%$ & NA & NA & 65 \\
\hline
\end{tabular}


Table 11 Sensitivity and specificity of Galectin 3 for malignancy, plus total number and percent of cases with positive immunoexpression (Continued)

\begin{tabular}{|c|c|c|c|c|c|c|c|c|c|c|c|c|c|c|c|c|c|c|c|c|c|c|c|c|}
\hline Gaffney RL (2003) [56] & 14 & $21 \%$ & 81 & $85 \%$ & & & 14 & $21 \%$ & & & & 21 & $67 \%$ & 60 & $92 \%$ & & & & & $85 \%$ & $79 \%$ & other & No & 95 \\
\hline Martins L (2002) [57] & 60 & $32 \%$ & 32 & $94 \%$ & 29 & $14 \%$ & 31 & $45 \%$ & & & & 20 & $90 \%$ & 12 & $100 \%$ & & & & & $94 \%$ & $68 \%$ & other & No & 92 \\
\hline Coli A (2002) [58] & 52 & $46 \%$ & 38 & $92 \%$ & & & 27 & $63 \%$ & 25 & $28 \%$ & & 5 & $60 \%$ & 28 & $100 \%$ & 1 & $100 \%$ & & & $92 \%$ & $54 \%$ & $>0 \%$ & No & 90 \\
\hline Nascimento MC (2001) [59] & 82 & $2 \%$ & 42 & $71 \%$ & 48 & $0 \%$ & 9 & $11 \%$ & & 14 & $7 \%$ & 14 & $79 \%$ & 11 & $82 \%$ & 17 & $59 \%$ & & & $71 \%$ & $98 \%$ & $>0 \%$ & No & 124 \\
\hline Nechifor-Boilă A (2014) [11] & 11 & $0 \%$ & 11 & $46 \%$ & 3 & $0 \%$ & 5 & $0 \%$ & & & & & & 11 & $46 \%$ & & & 5 & $0 \%$ & $46 \%$ & $100 \%$ & $10 \%$ & Yes & 22 \\
\hline Jang MH (2015) [32] & 113 & $4 \%$ & 79 & $8 \%$ & 41 & $2 \%$ & 72 & $6 \%$ & & & & 79 & $8 \%$ & & & & & & & $8 \%$ & $96 \%$ & $10 \%$ & Yes & 192 \\
\hline Abd-El Raouf SM (2014) [35] & 22 & $9 \%$ & 28 & $93 \%$ & 13 & $7 \%$ & 9 & $11 \%$ & & & & 5 & $80 \%$ & 23 & $96 \%$ & & & 5 & $80 \%$ & $93 \%$ & $91 \%$ & $10 \%$ & No & 50 \\
\hline Manivannan P (2012) [60] & 12 & $17 \%$ & 10 & $100 \%$ & & & & & & & & 3 & $100 \%$ & & & & & 7 & $100 \%$ & $100 \%$ & $83 \%$ & $10 \%$ & No & 22 \\
\hline Total & 2624 & & 2802 & & 932 & & 748 & & 466 & 106 & & 488 & & 1947 & & 155 & & 310 & & & & & & \\
\hline
\end{tabular}

NG/N nodular goiter/normal, FA follicular adenoma, HA hyperplastic adenoma, HCA Hurthle cell adenoma, FTC follicular thyroid carcinoma, HCC Hurthle cell carcinoma, FVPTC folicular variant of papillary thyroid carcinoma, Sens sensitivity, Spec specificity, TMA tissue microarray, NA not available, ukn unknown 
Table 12 Sensitivity and specificity for malignant cases of CD56 (total number and percent of cases with positive immunoexpression)

\begin{tabular}{|c|c|c|c|c|c|c|c|c|c|c|c|c|c|c|c|c|c|c|c|c|c|c|c|c|c|}
\hline \multirow[t]{2}{*}{ Reference } & \multicolumn{2}{|c|}{ Benign } & \multicolumn{2}{|c|}{ Malignant } & \multirow{2}{*}{$\begin{array}{l}N G \\
N\end{array}$} & \multirow{2}{*}{$\%$} & \multirow{2}{*}{$\begin{array}{l}\text { FA } \\
N\end{array}$} & \multirow[b]{2}{*}{$\%$} & \multirow{2}{*}{$\begin{array}{l}\mathrm{HA} \\
\mathrm{N}\end{array}$} & \multirow{2}{*}{$\%$} & \multicolumn{2}{|c|}{ HCA } & \multicolumn{2}{|c|}{ FTC } & \multicolumn{2}{|l|}{ PTC } & \multicolumn{2}{|c|}{$\mathrm{HCC}$} & \multicolumn{2}{|c|}{ FVPTC } & \multirow[b]{2}{*}{ Sens } & \multirow[b]{2}{*}{ Spec } & \multirow[b]{2}{*}{ Cut off } & \multirow[b]{2}{*}{ TMA } & \multirow[b]{2}{*}{ Total } \\
\hline & $\mathrm{N}$ & $\%$ & $\mathrm{~N}$ & $\%$ & & & & & & & $\mathrm{~N}$ & $\%$ & N & $\%$ & N & $\%$ & $\mathrm{~N}$ & $\%$ & $\mathrm{~N}$ & $\%$ & & & & & \\
\hline Dunđerović (2015) & 79 & $92 \%$ & 122 & $42 \%$ & 30 & $87 \%$ & 27 & $96 \%$ & 12 & $100 \%$ & 10 & $90 \%$ & 15 & $73 \%$ & 87 & $25 \%$ & 20 & $90 \%$ & 40 & $38 \%$ & $58 \%$ & $92 \%$ & $10 \%$ & yes & 201 \\
\hline Shahebrahimi K (2013) [64] & 39 & $92 \%$ & 39 & $5 \%$ & 32 & NA & 7 & NA & & & & & & & 39 & $5 \%$ & & & 5 & NA & $95 \%$ & $92 \%$ & $0 \%$ & no & 78 \\
\hline Nechifor-Boilă A (2014) [1 1] & 11 & $64 \%$ & 11 & $18 \%$ & 3 & $33 \%$ & 5 & $60 \%$ & & & & & & & 11 & $18 \%$ & & & 5 & $20 \%$ & $82 \%$ & $64 \%$ & $10 \%$ & yes & 22 \\
\hline Abd El Atti RM (2012) [65] & 44 & $93 \%$ & 29 & $17 \%$ & & & 12 & $92 \%$ & 32 & $88 \%$ & & & & & 29 & $17 \%$ & & & 16 & $19 \%$ & $83 \%$ & $93 \%$ & $10 \%$ & no & 73 \\
\hline Scarpino S (2007) [61] & 107 & $100 \%$ & 66 & $27 \%$ & & & 26 & $100 \%$ & & & & & & & 61 & $30 \%$ & & & 21 & $10 \%$ & $73 \%$ & $100 \%$ & other & no & 173 \\
\hline EIDemellawy D (2009) [62] & 100 & $100 \%$ & 75 & $0 \%$ & & & & & & & & & 2 & NA & 72 & $0 \%$ & 1 & NA & 23 & $0 \%$ & $100 \%$ & $100 \%$ & $10 \%$ & no & 175 \\
\hline Satoh F (2001) [68] & 11 & $46 \%$ & 39 & $8 \%$ & & & 11 & $46 \%$ & & & & & 10 & $0 \%$ & 14 & $7 \%$ & & & & & $92 \%$ & $46 \%$ & $0 \%$ & no & 50 \\
\hline Park WY (2009) [63] & 36 & $92 \%$ & 112 & $38 \%$ & 21 & $91 \%$ & 15 & $93 \%$ & & & & & 23 & $83 \%$ & 67 & $8 \%$ & & & & & $63 \%$ & $92 \%$ & $10 \%$ & no & 148 \\
\hline Nechifor-Boila A (2013) [69] & NA & $83 \%$ & 204 & $15 \%$ & & & & & & & & & & & 204 & $15 \%$ & & & 90 & $27 \%$ & $85 \%$ & $83 \%$ & $10 \%$ & yes & 204 \\
\hline Mi KS (2011) [66] & 22 & $73 \%$ & 80 & $5 \%$ & 12 & $58 \%$ & 5 & $100 \%$ & & & & & & & 80 & $5 \%$ & & & & & $95 \%$ & $73 \%$ & $10 \%$ & no & 102 \\
\hline Total & 449 & & 777 & & 98 & & 108 & & 44 & & & & 50 & & 664 & & 21 & & 200 & & & & & & 1226 \\
\hline
\end{tabular}

NG/N nodular goiter/normal, FA follicular adenoma, HA hyperplastic adenoma, HCA Hurthle cell adenoma, FTC follicular thyroid carcinoma, HCC Hurthle cell carcinoma, FVPTC folicular variant of papillary thyroid carcinoma, NA not available, Sens sensitivity, Spec specificity, TMA tissue microarray, NA not available 
Table 13 Sensitivity and specificity (summary of all reviewed studies)

\begin{tabular}{|c|c|c|c|c|c|c|c|c|}
\hline & & $M / B^{a}$ & PTC/FA & FVPTC/ FA & FVPTC/FTC & FTC/FA & $\mathrm{PTC} / \mathrm{NT}^{\mathrm{b}}$ & $\mathrm{HCC} / \mathrm{HCA}$ \\
\hline \multirow[t]{2}{*}{ CK19 } & Sensitivity & $80 \%$ & $90 \%$ & $74 \%$ & $74 \%$ & $28 \%$ & $90 \%$ & $51 \%$ \\
\hline & Specificity & $78 \%$ & $77 \%$ & $77 \%$ & $72 \%$ & $77 \%$ & $82 \%$ & $57 \%$ \\
\hline \multirow[t]{2}{*}{ HBME1 } & Sensitivity & $76 \%$ & $88 \%$ & $77 \%$ & $77 \%$ & $64 \%$ & $88 \%$ & $35 \%$ \\
\hline & Specificity & $87 \%$ & $73 \%$ & $73 \%$ & $36 \%$ & $73 \%$ & $93 \%$ & $57 \%$ \\
\hline \multirow[t]{2}{*}{ GAL 3} & Sensitivity & $84 \%$ & $93 \%$ & $81 \%$ & $81 \%$ & $50 \%$ & $93 \%$ & $88 \%$ \\
\hline & Specificity & $83 \%$ & $78 \%$ & $78 \%$ & $50 \%$ & 78 \% & $86 \%$ & $77 \%$ \\
\hline \multirow[t]{2}{*}{ CD56 } & Sensitivity & $80 \%$ & $86 \%$ & $78 \%$ & $78 \%$ & $40 \%$ & $86 \%$ & $10 \%$ \\
\hline & Specificity & $93 \%$ & $83 \%$ & $83 \%$ & $60 \%$ & $83 \%$ & $54 \%$ & $90 \%$ \\
\hline
\end{tabular}

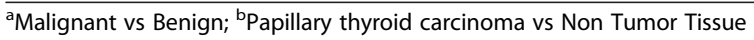

varied from $8-100 \%$ (median $=88 \%$ ), and $40-100 \%$ (median $=82 \%$ ) for specificity. The average values were not much different from median values ( $84 \%$; $83 \%)$.

The percent of immunopositive cases for control groups (non-tumour), follicular adenomas, follicular carcinomas and papillary carcinomas have varied greatly: $0-52 \%($ median $=8 \%) ; 0-63 \%($ median $=17 \%) ; 8-100 \%($ median $=$ $66 \%) ; 46-100 \%($ median $=93 \%)$, respectively.

Three markers co-expression (HBME1,Gal-3,CK19) had sensitivities of $83 \%, 87 \%$, and $54 \%$ as well as specificities of $100 \%, 89 \%$ and $100 \%$, respectively [14, 16, 27]. Concurrent absence had sensitivity of $38 \%$ and specificity of $100 \%$ for benign [14].

In the study of Zhu X et al. [15], more than three immunohistochemical markers were simultaneously positive in $100 \%$ of PTC cases and in $0-30 \%$ of patients with other types of disease.

CD56 is a neural cell adhesion molecule (NCAM), which is expressed normally in thyroid follicular cells. Reduced CD56 expression is correlated with tumour progression of patients with cancer. Its expression is reduced, or totally lost, in cases of papillary carcinoma, follicular carcinoma and anaplastic carcinoma [61-63].

The results of our study showed that malignant tumours had lost or expressed CD56 less than benign thyroid lesions, which is in agreement with previously published data [64-66]. CD56 expression is more reduced in papillary carcinomas in respect to follicular carcinomas and follicular adenomas [62, 63].

On the other side, we had not found significant difference in CD56 expression between follicular variant of papillary carcinoma and follicular carcinoma what is partially supported with results of other study [67]. Intriguingly, we found the difference in expression between follicular carcinoma and follicular adenoma, which is in disagreement with results of other authors [62-64]. If we connect previous information with findings that follicular carcinomas has significantly reduced expression of CD56 relative to benign follicular lesions we could conclude that reduces expression of CD56 is not exclusive property of papillary carcinoma.

Variation among studies in respect to sensitivity and specificity was substantial [11, 61-66, 68, 69]. Sensitivity for carcinoma varied from 58 to $100 \%$ with a median value of $84 \%$ (recalculated average value for all studies is $80 \%$ ). Specificity values ranged from 46 to $100 \%$, with a median value of $92 \%$ (recalculated average value for all studies is $93 \%$ ).

The highest sensitivity this marker shows for papillary carcinoma, and the lowest for follicular carcinoma.

Having in mind that we have obtained tissue cores from tumour periphery, our results could be substantiated by the results of other studies [61, 62], which found that within the PTC groups, occasional CD56-positive cells were identified, and in all cases, these cells were located at the tumour/non-tumour interface. Therefore, the low value of sensitivity (58 \%) of CD56 in our investigation might be the result of tissue sampling.

Nechifor-Boilă A et al. [11] found that panels consisting of CD56 and/or CK19/Gal-3 (they used Gal-3/CK19 formula because similar results were obtained in the panels containing either CK19 or Gal-3), and CD56 and/ or HBME-1 had highest sensitivities (90.9 \%) and negative predictive values ( 87.5 and 83.3 , respectively), while the most specific combination of markers was represented by association of HBME-1 with CK19/Gal-3 $(72.7 \%)$ in identifying PTC cases. The panel consisting of CD56 and/or HMBE-1 was highly sensitive and specific $(100 \%, 90 \%)$ in differentiating cases of FVPTC from benign thyroid lesions/tumours. When threemarker panels were evaluated, the best combination for FVPTC cases was HBME-1, CD56 and/or CK19, with a sensitivity reaching $91.1 \%$ [69]. In the studies of Mi KS et al. [66] and W Y Park et al. [63], sensitivities were 93,8 \% and $88.1 \%$ and specificities were $90.9 \%$ and 93.8 \% respectively, to distinguish PTC from other benign thyroid lesions with the combination of three markers CD56, GAL3, and CK19. 
This marked heterogeneity of diagnostic value of investigated markers could stem from few reasons. Primarily, cut off values varied from more than 0 to $25 \%$ of positive cells. Secondarily, some study designs included other tumours beside well differentiated thyroid carcinomas. Further, there is still no consensus about technical points, e.g., HMBE-1 membranous and/or cytoplasmatic staining delivers significant amount of freedom in deciding what is positive. Lastly, some studies employed TMA, others not. At the end, there are results which showed that more than one marker could be co-expressed even in benign lesions, which oblige us to continue the quest of searching more reliable markers. Until then, H\&E slides stays golden standard in diagnostics of follicular cells thyroid lesions.

It will not be fair not to mention weaknesses of this study. We shed some light to tumour/normal tissue interface, but we did not have proper representatives of tissue from tumours core. The number of cases, especially Hurthle cell adenomas, and follicular adenomas, was borderline. Some authors also claim that is mistake to include Hurthle cell tumours, but from practical standpoint, because we experienced real dilemmas if tumour is papillary carcinoma (oncocytic variant) or Hurthle cell adenoma for example, we included those tumours also.

\section{Conclusions}

In conclusion we may say that Galectin 3 is most sensitive marker for malignancy, while absence of expression of CD56 is very specific for malignancy. Expected coexpression for combinations of markers in diagnostics of follicular lesions decrease sensitivity and increase specificity for malignancy.

\footnotetext{
Abbreviations

FA: Follicular adenoma; FTC: Follicular thyroid carcinoma; FT-UMP: Follicular tumour of uncertain malignant potential; FVPTC: Folicular variant of papillary thyroid carcinoma; HA: Hurthle cell adenoma; HCC: Hurthle cell carcinoma; PTC: Papillary thyroid carcinoma; ROC: Receiver Operating Curve; TMA: Tissue microarray; WDT-UMP: Well differentiated tumours of uncertain malignant potential.
}

\section{Competing interests}

The authors declare that they have no competing interests.

\section{Authors' contributions}

DD conceived the study idea, designed the study along with ST, made the TMAs, evaluated immunohistochemical staining, interpreted data, and drafted the manuscript. JML and IB reviewed the literature, reviewed and edited the manuscript. IS performed statistical analyses and data interpretation. VB evaluated glass slides and extracted data. DC carried out immunohistochemical analysis and data interpretation. ST participated in conceiving the study, coordination and its design, evaluated glass slides along with DD and VB, evaluated immunohistochemical staining, and helped to draft the manuscript. All authors read and approved the final manuscript.

\section{Acknowledgments}

This work was supported by Ministry of Education and Science of Republic of Serbia, Grant No 175047.

\section{Author details}

${ }^{1}$ Institute of Pathology, Faculty of Medicine, University of Belgrade, dr Subotica 1, 11000 Belgrade, Serbia. ${ }^{2}$ Department of Pathology, Centre for Endocrine Surgery, Clinic for Diabetes and Metabolic Diseases, Clinical Center of Serbia, Dr. Koste Todorovića 8, 11000 Belgrade, Serbia. ${ }^{3}$ Institute for the application of nuclear energy, Belgrade, Serbia, Banatska 31b, Zemun, 11080 Zemun, Serbia. ${ }^{4}$ Faculty of Medicine, University of Belgrade, dr Subotica 8, 11000 Belgrade, Serbia.

Received: 2 July 2015 Accepted: 17 October 2015

Published online: 26 October 2015

\section{References}

1. Sternberg's Diagnostic Surgical Pathology (2-Volume Set). Carter D, Greenson JK, Reuter VE, Stoler MH, Mills SE, editors: LWW; 2009; 3104 p.

2. Gharib H, Papini E. Thyroid nodules: clinical importance, assessment, and treatment. Endocrinol Metab Clin North Am. 2007;36(3):707-35.

3. Murray D. In: Kovacs KaA S, ed. The thyroid gland. Malden: Blackwell Science, 1998:295-380.

4. Mete O, Asa SL. Pitfalls in the diagnosis of follicular epithelial proliferations of the thyroid. Adv Anat Pathol. 2012;19(6):363-73.

5. Rosai J. The encapsulated follicular variant of papillary thyroid carcinoma: back to the drawing board. Endocr Pathol. 2010;21(1):7-11.

6. Liu Z, Zhou G, Nakamura M, Koike E, Li Y, Ozaki T, et al. Encapsulated follicular thyroid tumor with equivocal nuclear changes, so-called well-differentiated tumor of uncertain malignant potential: a morphological, immunohistochemical, and molecular appraisal. Cancer Sci. 2011;102(1):288-94.

7. Boerner SL, Asa SL. Biopsy Interpretation of the Thyroid. Philadelphia: Lippincott Williams \& Wilkins; 2010.

8. Cibas ES, Baloch ZW, Fellegara G, LiVolsi VA, Raab SS, Rosai J, et al. A prospective assessment defining the limitations of thyroid nodule pathologic evaluation. Ann Intern Med. 2013;159(5):325-32.

9. Ozolins A, Narbuts Z, Strumfa I, Volanska G, Stepanovs K, Gardovskis J. Immunohistochemical expression of HBME-1, E-cadherin, and CD56 in the differential diagnosis of thyroid nodules. Medicina (Kaunas). 2012;48(10):507-14.

10. Park YJ, Kwak SH, Kim DC, Kim H, Choe G, Park do J, et al. Diagnostic value of galectin-3, HBME-1, cytokeratin 19, high molecular weight cytokeratin, cyclin D1 and p27(kip1) in the differential diagnosis of thyroid nodules. J Korean Med Sci. 2007;22(4):621-8.

11. Nechifor-Boila A, Catana R, Loghin A, Radu TG, Borda A. Diagnostic value of HBME-1, CD56, Galectin-3 and Cytokeratin-19 in papillary thyroid carcinomas and thyroid tumors of uncertain malignant potential. Rom J Morphol Embryol. 2014;55(1):49-56.

12. Kwaspen FH, Smedts FM, Broos A, Bulten H, Debie WM, Ramaekers FC. Reproducible and highly sensitive detection of the broad spectrum epithelial marker keratin 19 in routine cancer diagnosis. Histopathology. 1997;31(6):503-16.

13. Sethi K, Sarkar S, Das S, Mohanty B, Mandal M. Biomarkers for the diagnosis of thyroid cancer. J Exp Ther Oncol. 2010;8(4):341-52.

14. Barroeta JE, Baloch ZW, Lal P, Pasha TL, Zhang PJ, LiVolsi VA. Diagnostic value of differential expression of CK19, Galectin-3, HBME-1, ERK, RET, and p16 in benign and malignant follicular-derived lesions of the thyroid: an immunohistochemical tissue microarray analysis. Endocr Pathol. 2006;17(3):225-34.

15. Zhu X, Sun T, Lu H, Zhou X, Lu Y, Cai X. Diagnostic significance of CK19, RET, galectin-3 and HBME-1 expression for papillary thyroid carcinoma. J Clin Pathol. 2010;63(9):786-9.

16. Scognamiglio T, Hyjek E, Kao J, Chen YT. Diagnostic usefulness of HBME1, galectin-3, CK19, and CITED1 and evaluation of their expression in encapsulated lesions with questionable features of papillary thyroid carcinoma. Am J Clin Pathol. 2006;126(5):700-8.

17. Nasr MR, Mukhopadhyay S, Zhang S, Katzenstein AL. Immunohistochemical markers in diagnosis of papillary thyroid carcinoma: Utility of HBME1 combined with CK19 immunostaining. Mod Pathol. 2006;19(12):1631-7.

18. Prasad ML, Pellegata NS, Huang Y, Nagaraja HN, de la Chapelle A, Kloos RT. Galectin-3, fibronectin-1, CITED-1, HBME1 and cytokeratin-19 immunohistochemistry is useful for the differential diagnosis of thyroid tumors. Mod Pathol. 2005;18(1):48-57.

19. Casey MB, Lohse CM, Lloyd RV. Distinction between papillary thyroid hyperplasia and papillary thyroid carcinoma by immunohistochemical 
staining for cytokeratin 19, galectin-3, and HBME-1. Endocr Pathol. 2003;14(1):55-60.

20. Erkilic S, Aydin A, Kocer NE. Diagnostic utility of cytokeratin 19 expression in multinodular goiter with papillary areas and papillary carcinoma of thyroid. Endocr Pathol. 2002;13(3):207-11.

21. Sahoo S, Hoda SA, Rosai J, DeLellis RA. Cytokeratin 19 immunoreactivity in the diagnosis of papillary thyroid carcinoma: a note of caution. Am J Clin Pathol. 2001;116(5):696-702.

22. Cheung CC, Ezzat S, Freeman JL, Rosen IB, Asa SL. Immunohistochemical diagnosis of papillary thyroid carcinoma. Mod Pathol. 2001;14(4):338-42.

23. Barut F, Onak Kandemir N, Bektas S, Bahadir B, Keser S, Ozdamar SO. Universal markers of thyroid malignancies: galectin-3, HBME-1, and cytokeratin-19. Endocr Pathol. 2010;21(2):80-9.

24. Wiseman SM, Melck A, Masoudi H, Ghaidi F, Goldstein L, Gown A, et al. Molecular phenotyping of thyroid tumors identifies a marker panel for differentiated thyroid cancer diagnosis. Ann Surg Oncol. 2008;15(10):2811-26.

25. Liu YY, Morreau H, Kievit J, Romijn JA, Carrasco N, Smit JW. Combined immunostaining with galectin-3, fibronectin-1, CITED-1, Hector Battifora mesothelial-1, cytokeratin-19, peroxisome proliferator-activated receptor-\{gamma\}, and sodium/iodide symporter antibodies for the differential diagnosis of nonmedullary thyroid carcinoma. Eur J Endocrinol. 2008;158(3):375-84.

26. Murphy KM, Chen F, Clark DP. Identification of immunohistochemical biomarkers for papillary thyroid carcinoma using gene expression profiling. Hum Pathol. 2008;39(3):420-6.

27. Nakamura N, Erickson LA, Jin L, Kajita S, Zhang H, Qian X, et al. Immunohistochemical separation of follicular variant of papillary thyroid carcinoma from follicular adenoma. Endocr Pathol. 2006;17(3):213-23.

28. Rossi ED, Raffaelli M, Mule A, Miraglia A, Lombardi CP, Vecchio FM, et al. Simultaneous immunohistochemical expression of HBME-1 and galectin-3 differentiates papillary carcinomas from hyperfunctioning lesions of the thyroid. Histopathology. 2006;48(7):795-800.

29. Song Q, Wang D, Lou Y, Li C, Fang C, He X, et al. Diagnostic significance of CK19, TG, Ki67 and galectin-3 expression for papillary thyroid carcinoma in the northeastern region of China. Diagn Pathol. 2011;6:126.

30. Beesley MF, McLaren KM. Cytokeratin 19 and galectin-3 immunohistochemistry in the differential diagnosis of solitary thyroid nodules. Histopathology. 2002;41(3):236-43.

31. de Matos PS, Ferreira AP, de Oliveira FF, Assumpcao LV, Metze K, Ward LS. Usefulness of HBME-1, cytokeratin 19 and galectin-3 immunostaining in the diagnosis of thyroid malignancy. Histopathology. 2005;47(4):391-401.

32. Jang MH, Jung KC, Min HS. The Diagnostic Usefulness of HMGA2, Survivin, CEACAM6, and SFN/14-3-3 delta in Follicular Thyroid Carcinoma. J Pathol Transl Med. 2015;49(2):112-7.

33. Yassin FE. Diagnostic criteria of well differentiated thyroid tumor of uncertain malignant potential; a histomorphological and immunohistochemical appraisal. J Egypt Natl Canc Inst. 2015;27:59.

34. Choi YL, Kim MK, Suh JW, Han J, Kim JH, Yang JH, et al. Immunoexpression of HBME-1, high molecular weight cytokeratin, cytokeratin 19, thyroid transcription factor-1, and E-cadherin in thyroid carcinomas. J Korean Med Sci. 2005;20(5):853-9.

35. Abd-El Raouf SM, Ibrahim TR. Immunohistochemical expression of HBME-1 and galectin-3 in the differential diagnosis of follicular-derived thyroid nodules. Pathol Res Pract. 2014:210(12):971-8.

36. Nikiforova MN, Lynch RA, Biddinger PW, Alexander EK, Dorn 2nd GW, Tallini G, et al. RAS point mutations and PAX8-PPAR gamma rearrangement in thyroid tumors: evidence for distinct molecular pathways in thyroid follicular carcinoma. J Clin Endocrinol Metab. 2003:88(5):2318-26.

37. Mai KT, Bokhary R, Yazdi HM, Thomas J, Commons AS. Reduced HBME-1 immunoreactivity of papillary thyroid carcinoma and papillary thyroid carcinomarelated neoplastic lesions with Hurthle cell and/or apocrine-like changes. Histopathology. 2002;40(2):133-42.

38. Liang HS, Zhong YH, Luo ZJ, Huang Y, Lin HD, Luo M, et al. Comparative analysis of protein expression in differentiated thyroid tumours: a multicentre study. J Int Med Res. 2009;37(3):927-38.

39. Ito Y, Yoshida H, Tomoda C, Miya A, Kobayashi K, Matsuzuka F, et al. HBME-1 expression in follicular tumor of the thyroid: an investigation of whether it can be used as a marker to diagnose follicular carcinoma. Anticancer Res. 2005;25(1A):179-82.

40. Mase T, Funahashi H, Koshikawa T, Imai T, Nara Y, Tanaka Y, et al. HBME-1 immunostaining in thyroid tumors especially in follicular neoplasm. Endocr J. 2003;50(2):173-7.
41. Volante M, Bozzalla-Cassione F, DePompa R, Saggiorato E, Bartolazzi A, Orlandi F, et al. Galectin-3 and HBME-1 expression in oncocytic cell tumors of the thyroid. Virchows Arch. 2004;445(2):183-8.

42. Guo Z, Hardin H, Montemayor-Garcia C, Asioli S, Righi A, Maletta F, et al. In Situ Hybridization Analysis of miR-146b-5p and miR-21 in Thyroid Nodules: Diagnostic Implications. Endocr Pathol. 2015. [Epub ahead of print]

43. Liu FT, Rabinovich GA. Galectins as modulators of tumour progression. Nat Rev Cancer. 2005;5:29-41.

44. Xu XC, el-Naggar AK, Lotan R. Differential expression of galectin-1 and galectin-3 in thyroid tumors. Potential diagnostic implications. Am J Pathol. 1995;147:815-22

45. Inohara H, Segawa T, Miyauchi A, Yoshii T, Nakahara S, Raz A, et al. Cytoplasmic and serum galectin-3 in diagnosis of thyroid malignancies. Biochem Biophys Res Commun. 2008:376(3):605-10.

46. Aiad HA, Kandil MA, Asaad NY, El-Kased AM, El-Goday SF. Galectin-3 immunostaining in cytological and histopathological diagnosis of thyroid lesions. J Egypt Natl Canc Inst. 2008;20(1):36-46.

47. Sapio MR, Guerra A, Posca D, Limone PP, Deandrea M, Motta M, et al. Combined analysis of galectin-3 and BRAFV600E improves the accuracy of fine-needle aspiration biopsy with cytological findings suspicious for papillary thyroid carcinoma. Endocr Relat Cancer. 2007;14(4):1089-97.

48. Galusca B, Dumollard JM, Lassandre S, Niveleau A, Prades JM, Estour B, et al. Global DNA methylation evaluation: potential complementary marker in differential diagnosis of thyroid neoplasia. Virchows Arch. 2005;447(1):18-23.

49. Nucera C, Mazzon E, Caillou B, Violi MA, Moleti M, Priolo C, et al. Human galectin-3 immunoexpression in thyroid follicular adenomas with cell atypia. J Endocrinol Invest. 2005;28(2):106-12.

50. Weber KB, Shroyer KR, Heinz DE, Nawaz S, Said MS, Haugen BR. The use of a combination of galectin-3 and thyroid peroxidase for the diagnosis and prognosis of thyroid cancer. Am J Clin Pathol. 2004;122(4):524-31.

51. Torres-Cabala C, Panizo-Santos A, Krutzsch HC, Barazi H, Namba M, Sakaguchi M, et al. Differential expression of $\mathrm{S} 100 \mathrm{C}$ in thyroid lesions. Int J Surg Pathol. 2004;12(2):107-15.

52. Lavra L, Rinaldo C, Ulivieri A, Luciani E, Fidanza P, Giacomelli L, et al. The loss of the p53 activator HIPK2 is responsible for galectin-3 overexpression in well differentiated thyroid carcinomas. PLoS One. 2011;6(6):e20665.

53. Kovacs RB, Foldes J, Winkler G, Bodo M, Sapi Z. The investigation of galectin-3 in diseases of the thyroid gland. Eur J Endocrinol. 2003;149(5):449-53.

54. Jakubiak-Wielganowicz M, Kubiak R, Sygut J, Pomorski L, Kordek R. Usefulness of galectin-3 immunohistochemistry in differential diagnosis between thyroid follicular carcinoma and follicular adenoma. Pol J Pathol. 2003;54(2):111-5.

55. Giannini R, Faviana P, Cavinato T, Elisei R, Pacini F, Berti P, et al. Galectin-3 and oncofetal-fibronectin expression in thyroid neoplasia as assessed by reverse transcription-polymerase chain reaction and immunochemistry in cytologic and pathologic specimens. Thyroid. 2003;13(8):765-70.

56. Gaffney RL, Carney JA, Sebo TJ, Erickson LA, Volante M, Papotti M, et al. Galectin-3 expression in hyalinizing trabecular tumors of the thyroid gland. Am J Surg Pathol. 2003;27(4):494-8.

57. Martins L, Matsuo SE, Ebina KN, Kulcsar MA, Friguglietti CU, Kimura ET. Galectin-3 messenger ribonucleic acid and protein are expressed in benign thyroid tumors. J Clin Endocrinol Metab. 2002;87(10):4806-10.

58. Coli A, Bigotti G, Zucchetti F, Negro F, Massi G. Galectin-3, a marker of well-differentiated thyroid carcinoma, is expressed in thyroid nodules with cytological atypia. Histopathology. 2002;40(1):80-7.

59. Nascimento MC, Bisi H, Alves VA, Longatto-Filho A, Kanamura CT, Medeiros-Neto G. Differential reactivity for galectin-3 in Hurthle cell adenomas and carcinomas. Endocr Pathol. 2001;12(3):275-9.

60. Manivannan P, Siddaraju N, Jatiya L, Verma SK. Role of pro-angiogenic marker galectin-3 in follicular neoplasms of thyroid. Indian J Biochem Biophys. 2012;49(5):392-4.

61. Scarpino S, Di Napoli A, Melotti F, Talerico C, Cancrini A, Ruco L. Papillary carcinoma of the thyroid: low expression of NCAM (CD56) is associated with downregulation of VEGF-D production by tumour cells. J Pathol. 2007;212(4):411-9.

62. El Demellawy D, Nasr AL, Babay S, Alowami S. Diagnostic utility of CD56 immunohistochemistry in papillary carcinoma of the thyroid. Pathol Res Pract. 2009;205(5):303-9.

63. Park WY, Jeong SM, Lee JH, Kang HJ, Sin DH, Choi KU, et al. Diagnostic value of decreased expression of CD56 protein in papillary carcinoma of the thyroid gland. Basic and Applied Pathology. 2009;2:63-8. 
64. Shahebrahimi K, Madani SH, Fazaeli AR, Khazaei S, Kanani M, Keshavarz A. Diagnostic value of CD56 and nm23 markers in papillary thyroid carcinoma. Indian J Pathol Microbiol. 2013;56(1):2-5.

65. Abd El Atti RM, Shash LS. Potential diagnostic utility of CD56 and claudin-1 in papillary thyroid carcinoma and solitary follicular thyroid nodules. J Egypt Natl Canc Inst. 2012;24(4):175-84.

66. Mi KS, Jeong WK, Young SJ. CD56 and high molecular weight cytokeratin as diagnostic markers of papillary thyroid carcinoma. The Korean Journal of Pathology. 2011;45(5):477-84.

67. Etem H, Özekinci S, Mizrak B, Şentürk S. The Role of CD56, HBME-1, and p63 in Follicular Neoplasms of the Thyroid. Turk J Pathol. 2010;26(3):238-42.

68. Satoh F, Umemura S, Yasuda M, Osamura RY. Neuroendocrine marker expression in thyroid epithelial tumors. Endocr Pathol. 2001;12(3):291-9.

69. Nechifor-Boila A, Borda A, Sassolas G, Hafdi-Nejjari Z, Borson-Chazot F, Lifante JC, et al. Immunohistochemical markers in the diagnosis of papillary thyroid carcinomas: The promising role of combined immunostaining using HBME-1 and CD56. Pathol Res Pract. 2013;209(9):585-92.

70. Oestreicher-Kedem Y, Halpern M, Roizman P, Hardy B, Sulkes J, Feinmesser $R$, et al. Diagnostic value of galectin-3 as a marker for malignancy in follicular patterned thyroid lesions. Head Neck. 2004;26(11):960-6.

\section{Submit your next manuscript to BioMed Central and take full advantage of:}

- Convenient online submission

- Thorough peer review

- No space constraints or color figure charges

- Immediate publication on acceptance

- Inclusion in PubMed, CAS, Scopus and Google Scholar

- Research which is freely available for redistribution 